\title{
Litoral norte do estado do Rio Grande do Sul: indicadores socioeconômicos e principais problemas ambientais
}

\section{Rio Grande do Sul northern littoral: social-economic indicators and major environmental problems}

\author{
Nina Simone Vilaverde Moura FUJIMOTO* \\ Tânia Marques STROHAECKER ${ }^{* *}$ \\ Nelson Luís Sambaqui GRUBER*** \\ Aline Vicente KUNST ${ }^{* * * *}$ \\ Anelise Helm FERREIRA******
}

\begin{abstract}
RESUMO
A região do Litoral Norte, um dos segmentos da Zona Costeira do Rio Grande do Sul, distingue-se pela sequiência de ambientes longitudinais à costa. Após a área de interface com o mar, identifica-se uma planície sedimentar costeira, constituída por dunas, além de um rosário de lagoas litorâneas, chegando até as escarpas do Planalto Meridional, entalhadas pelos vales dos rios Maquiné e Três Forquilhas. As relações entre sociedade e natureza ampliaram-se nas últimas décadas e, em especial, na Zona Costeira por causa, entre outros fatores, do processo de urbanização. No entanto, esse rápido crescimento ocasionou uma série de problemas para um ambiente caracterizado por ecossistemas diversificados e de grande suscetibilidade. A análise do índice de desenvolvimento socioeconômico, elaborado pela Fundação de Economia e Estatística (FEE) do Estado do Rio Grande do Sul, classifica a região do Litoral Norte do Rio Grande do Sul dentro de um perfil de médio desenvolvimento. Os investimentos em saúde e educação realizados nos últimos anos melhoraram sensivelmente os indicadores da região. No entanto, é necessário canalizar mais recursos em setores-chave, principalmente no tocante à demanda pelo ensino médio, ao abastecimento de água por rede geral, à rede coletora e destinação do esgoto cloacal e ao destino final dos resíduos sólidos. Os problemas ambientais mais significativos, exacerbados nos meses de dezembro a março, são relativos ao abastecimento e a qualidade das águas,
\end{abstract}

\footnotetext{
* Professora no Departamento de Geografia, Pesquisadora do Ceco, Instituto de Geociências/UFRGS. Pesquisadora no Projeto Recos/Instituto do Milênio, GT Monitoramento, Modelagem e Ocupação Costeira, Subgrupo Uso e Ocupação do Solo. Doutora pela USP. nina.fujimoto@ufrgs.br

** Professora no Departamento de Geografia, Pesquisadora do Ceco, Instituto de Geociências/UFRGS. Pesquisadora no Projeto Recos/Instituto do Milênio, GT Monitoramento, Modelagem e Ocupação Costeira, Subgrupo Uso e Ocupação do Solo. Doutoranda no Programa de Pós-Graduação em Geociências/UFRGS, Área Geologia Marinha e Costeira. tania.strohaecker@ufrgs.br

*** Professor do Departamento de Geografia, Pesquisador do Ceco, Instituto de Geociências/UFRGS. Pesquisador no Projeto Recos/Instituto do Milênio, GT Monitoramento, Modelagem e Ocupação Costeira, Subgrupo Uso e Ocupação do Solo. Doutor pela UFRGS. nelson.gruber@ufrgs.br

**** Bolsista de Iniciação Científica/CNPq, Projeto Recos/Instituto do Milênio. Acadêmica do Curso de Bacharelado em Geografia/UFRGS. aline_kunst@yahoo.com.br ***** Bolsista de Iniciação Científica/CNPq, Projeto Recos/Instituto do Milênio. Acadêmica do Curso de Bacharelado em Geografia/UFRGS. geo_anelise@ yahoo.com.br
} 
a ampliação na demanda por serviços de saúde, a balneabilidade das praias, o esgotamento sanitário, a disposição dos resíduos sólidos, os conflitos de uso na faixa de praia, a ampliação no número de moradias irregulares, poluição hídrica, sonora e visual, entre outros.

Palavras-chave: litoral; indicadores socioeconômicos; problemas ambientais.

\section{ABSTRACT}

The north littoral region of Rio Grande do Sul is a coastal zone segment where a sequence of environments organized in a longitudinal orientation to the coast occurs. A sedimentary coastal plain is identified landwards from the shoreline, formed by dunes deposits and by interconnected coastal lagoons, and extending its area up to the scarps of the Planalto Meridional (basement highlands), which are deeply incised by the valleys of Maquiné and Três Forquilhas rivers. The relationships between society and nature have increased in the last decades, in special in the Coastal Zone, due to the urbanization processes, among other factors. However, the quick grow of urbanization resulted in some problems for an environment that is characterized by an ecosystem diversity of great sensibility. The analysis of the index of social-economic development allows classifying the north littoral region of Rio Grande do Sul in a profile of a medium development rate. The investments on healthy and education of the last years have increased the regional socio-economical indicators. However, more investments are necessary in key-sectors of the study area, mainly in respect to: the demand for high school opportunities, availability of water by a general net, collection and discharge of urban effluents and waste disposal. The most significant environmental changes, increased during summer months (December to March), are related to the high demand and quality of waters, the high demand for healthy services, beach quality, sanitary collapse, disposal of residual solids, conflicts on the use of the beach area, increase on the number of irregular properties, water, sound and visual pollution, a general lack of respect to the environment, among others.

Key-words: littoral; environmental problems; social-economic indicators.

\section{Introdução}

A Zona Costeira do Estado do Rio Grande do Sul caracteriza-se por apresentar uma planície sedimentar recente, do período Cenozóico, com ecossistemas raros e de grande vulnerabilidade. Essa paisagem, ainda em transformação, apresenta um conjunto de feições geomorfológicas sob condições de clima subtropical úmido costeiro em que se destacam as barreiras de dunas, os banhados, o cordão de lagoas e a escarpa do planalto, conferindo um cenário diferenciado no continente latino-americano.

A região do Litoral Norte, um dos segmentos da Zona Costeira do Rio Grande do Sul, caracteriza-se pela seqüência de ambientes longitudinais à costa, chegando até as escarpas do Planalto Meridional. Após a área de interface com o mar, identifica-se uma planície sedimentar costeira, composta por dunas, seguidas pelo cordão de lagoas litorâneas até o contato com a escarpa do Planalto Meridional, entalhada pelos vales dos rios Maquiné e Três Forquilhas.
O estado do Rio Grande do Sul esteve submetido, nas últimas décadas, a um processo de emancipações municipais relativamente intenso quando comparado com outros estados e regiões brasileiras. O Litoral Norte do Rio Grande do Sul, seguindo a tendência estadual, passou por um processo recente de emancipações. Em 1965, os municípios de Santo Antônio da Patrulha, Osório, Torres e Tramandaí, a partir de seus limites político-administrativos, representavam, conjuntamente, o território do Litoral Norte considerado neste trabalho. Nas décadas seguintes, principalmente 1980 e 1990, surgem mais 17 novos municípios, os quais foram criados a partir de desmembramentos nos territórios dos municípios anteriormente citados. Atualmente são 21 municípios que compõem a região do Litoral Norte. As emancipações desempenharam um papel fundamental no desenvolvimento da região e do estado de uma forma geral, tendo em vista os investimentos no setor rodoviário, no setor imobiliário, e as melhorias na infraestrutura. No entanto, os dados de infra-estrutura dos municípios do Litoral Norte do Rio Grande do Sul apontam 
deficiências no que diz respeito ao saneamento básico, coleta de resíduos sólidos, além de se observar um crescimento no número de moradias irregulares (favelas), principalmente nos municípios com maior número de população residente, e uma série de alterações ambientais decorrentes do processo recente de urbanização.

No último decênio, o Litoral Norte apresentou o maior crescimento populacional, em termos relativos, no estado do Rio Grande do Sul, com uma taxa anual aproximada de $2,83 \%$. Esse indicador é muito significativo se compararmos com as taxas anuais do estado $(1,23 \%)$ e do Brasil $(1,63 \%)$. A taxa de crescimento médio anual é a segunda maior do Estado, ficando abaixo apenas da região metropolitana de Porto Alegre (1,69\%). Alguns municípios do Litoral Norte apresentaram taxas de crescimento anuais superiores a 5\%, como Balneário Pinhal (7,56\%), Cidreira (6,71\%), Arroio do Sal (6,41\%), Imbé (5,89\%), Capão da Canoa $(5,16 \%)$ e Xangri-lá $(5,05 \%)$ (RIO GRANDE DO SUL, 2002).

O presente trabalho tem como objetivo geral caracterizar o uso e a ocupação do solo nos municípios do Litoral Norte do estado do Rio Grande do Sul, analisando os indicadores socioeconômicos e as alterações ambientais decorrentes das diversas formas de apropriação da natureza. Como objetivos específicos, o estudo procura: a) caracterizar o meio físico a partir dos compartimentos geomorfológicos e do Zoneamento Ecológico-Econômico, desenvolvido pelo Programa de Gerenciamento Costeiro (Gerco) (RIO GRANDE DO SUL, 2000); b) caracterizar a região do ponto de vista socioeconômico a partir da análise de indicadores sociais (educação, saúde, renda, saneamento e domicílios) e econômicos (valor adicionado bruto, infra-estrutura); c) identificar e caracterizar as principais alterações ambientais da região a partir da análise do meio físico e da ocupação do solo, classificando-os de acordo com os perfis dos municípios.

\section{Procedimentos metodológicos e operacionais}

A regionalização adotada para desenvolver esse estudo no Litoral Norte destaca fatores de homogeneidade que o definem como uma unidade de estudo no estado do Rio Grande do Sul, pois procura contemplar a área física estabelecida pelo Programa de Gerenciamento Costeiro (Gerco) e os aspectos político-administrativos (divisão municipal). Dessa forma, a abordagem engloba um con- junto de 21 municípios, a saber: Arroio do Sal, Balneário Pinhal, Capão da Canoa, Capivari do Sul, Caraá, Cidreira, Dom Pedro de Alcântara, Imbé, Itati, Mampituba, Maquiné, Morrinhos do Sul, Osório, Palmares do Sul, Santo Antônio da Patrulha, Terra de Areia, Torres, Tramandaí, Três Cachoeiras, Três Forquilhas e Xangri-lá.

Diante dessa regionalização, que define os 21 municípios como uma unidade de estudo, procurou-se, neste trabalho, desenvolver uma metodologia de múltiplas heterogeneidades. Essa metodologia buscou agrupar os municípios do Litoral Norte em função de diferenças e semelhanças para facilitar a compreensão do espaço geográfico. A partir da análise realizada pode-se propor uma classificação para o Litoral Norte do estado do Rio Grande do Sul de quatro grupos distintos de municípios, segundo agrupamentos de características semelhantes, que são: população rural e urbana do município, domicílios ocupados e o Valor Adicionado Bruto, representado nos setores agropecuário, industrial, comercial e demais serviços. À análise destes indicadores principais soma-se também a análise dos dados de migração, índices de qualidade de vida e infra-estrutura, bem como a pesquisa da formação territorial dos municípios que compõem a região. Os grupos identificados são (Figura 1): municípios urbanos com população permanente, municípios urbanos com perfil de segunda residência, municípios urbanos com população permanente ocupada com atividades agroindustriais e municípios rurais (ғUлімото et al., 2005).

Os municípios que se caracterizam por serem urbanos com população permanente são: Capão da Canoa, Osório, Tramandaí e Torres. Esses municípios têm características predominantemente urbanas e um significativo número de domicílios ocupados o ano inteiro. São municípios antigos localizados junto à orla, e de seus territórios foram desmembrados muitos municípios com perfil atualmente de segunda residência. Constatou-se que, mesmo com as emancipações, esses municípios não perderam população, ao contrário, apresentaram incremento populacional decorrente de suas funções polarizadoras na região no tocante à concentração de investimentos públicos e privados.

Os municípios urbanos com perfil de segunda residência são: Arroio do Sal, Balneário Pinhal, Cidreira, Imbé e Xangri-lá. Tais municípios caracterizam-se por estarem situados junto à orla e terem sido áreas de balneários antes de sua criação. Esse grupo apresenta uma população predominantemente urbana (95\%), pois a maior concentração de domicílios ocorre na área urbana. No entanto, menos de 


\section{FIGURA 1 - LOCALIZAÇÃO DO LITORAL NORTE DO ESTADO DO RIO GRANDE DO SUL}

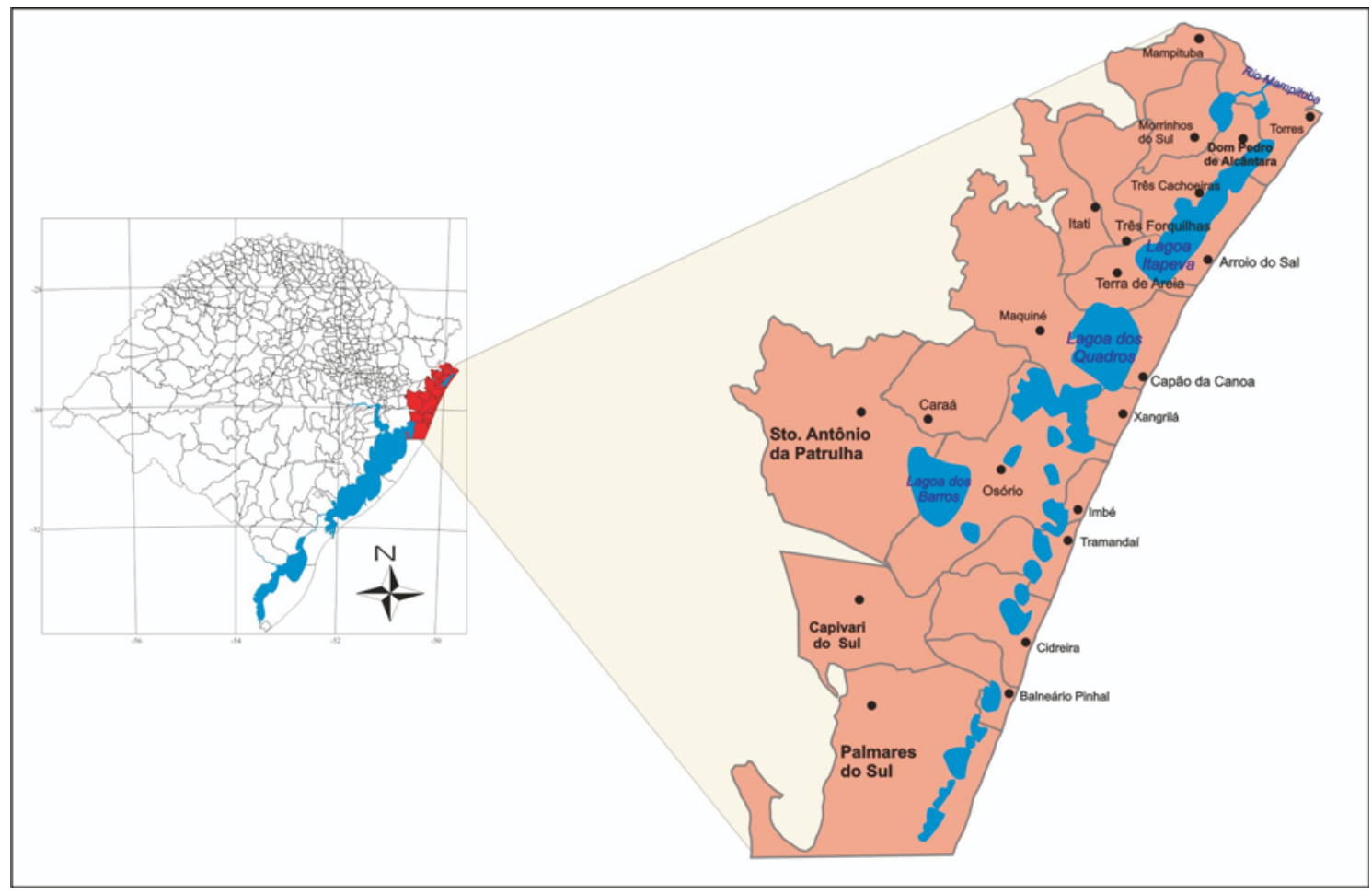

$20 \%$ dos domicílios são ocupados permanentemente, comprovando que se trata de municípios com perfil de segunda residência, com relevante aumento populacional nos meses de verão.

Os municípios urbanos com população permanente ocupada com atividades agroindustriais são: Santo Antônio da Patrulha, Capivari do Sul e Palmares do Sul. São municípios que têm população predominantemente urbana, e um número considerável de domicílios ocupados o ano inteiro. Eles se localizam nas áreas de planície lagunar, potencialmente adequada para a orizicultura e para o florestamento, associados às atividades industriais de beneficiamento desses cultivos, entre outras atividades industriais.

Os municípios rurais são: Três Cachoeiras, Maquiné, Caraá, Morrinhos do Sul, Três Forquilhas, Mampituba, Dom Pedro de Alcântara e Itati. A maioria desses municípios foi emancipada na década de 1990, com exceção de Três Cachoeiras, que foi criado em 1988. Esse grupo de municípios está localizado nas áreas de escarpa do Planalto Meridional, apresenta características predominantemente rurais, com estrutura fundiária baseada na pequena propriedade, com predominância da população rural, e sua economia está direcionada principalmente para o setor primário e, mais recentemente, também para o turismo ecológico.

Esta classificação destaca o local de residência da população e o elemento econômico mais marcante que explica em grande parte a situação atual. No entanto, não se pode negar a possibilidade de outras atividades em cada município e nem as semelhanças entre municípios de cada tipo.

A informação utilizada se baseia na revisão bibliográfica da literatura disponível e nos dados secundários mais recentes, produzidos por diversos órgãos públicos. As informações quanto às alterações ambientais foram coletadas em entrevistas nas prefeituras de quatro municípios, cada qual representativa de um grupo de municípios identificados na região do Litoral Norte. 


\section{Caracterização do meio físico do Litoral Norte do Rio Grande do Sul}

A caracterização do meio físico compreende uma análise das principais unidades que foram identificadas na área de estudo e no seu entorno, a partir da identificação das principais características geomorfológicas e do Zoneamento Ecológico-Econômico (ZEE) desenvolvido pelo Programa de Gerenciamento Costeiro (Gerco) para o Litoral Norte do estado do Rio Grande do Sul.

No âmbito das morfoesculturas, a área é constituída pelas unidades do Planalto Meridional e pela Planície de Terras Baixas Costeiras, segundo classificação de Ab'Saber (1964) apud Gonçalves e Santos (1985). Em cada unidade é possível identificar os principais tipos e formas de relevo na área de estudo por meio de sua caracterização morfológica, litológica, de cobertura vegetal e de uso da terra.

\section{Unidade do planalto meridional}

O Planalto Meridional está regionalmente nos domínios da Bacia Sedimentar do Paraná, segundo Horn Filho (1987). Litologicamente, na área de estudo, o Planalto está representado na base pela Formação Botucatu, do período Triássico/Jurássico, originada em um ambiente climático desértico. Essa formação é constituída por sedimentos arenosos com estratificação cruzada eólica sotopostos ou intercalados às lavas básicas/ácidas da Formação Serra Geral.

No litoral norte, a morfoescultura do Planalto Meridional está representada, predominantemente, pela escarpa de falha do referido planalto. A origem dessa escarpa está associada ao rompimento do Gondwana, que levou à separação da América do Sul e da África, com a abertura do Oceano Atlântico. Grandes falhas segmentaram o Gondwana, e por elas extravasou enorme volume de lavas que formaram as sucessivas camadas de rochas vulcânicas do Planalto Meridional do Rio Grande do Sul e adjacente. Estes são denominados geologicamente de Formação Serra Geral. Os falhamentos com basculamentos e abatimento do bloco oriental do Gondwana sob a forma de degraus dos derrames basálticos deram origem à escarpa de falha, hoje recuada por erosão, no espaço compreendido entre Osório e Torres no Rio Grande do Sul (suertegaray; FuJimoto, 2004).

A escarpa abrupta voltada para o oceano, representada por vales bem entalhados, por vertentes com declividades acentuadas e por formas em morros, é resultante do conjunto de fatores tectônicos e climáticos que atuaram sobre a superfície sustentada, predominantemente, pelas rochas da Formação Serra Geral. Ocorrem ainda as rampas coluviais, que são feições caracterizadas por depósitos de encosta, os quais são oriundos de processos gravitacionais ou originados de alterações in situ das rochas vulcânicas. Nessas áreas, os solos são mais profundos. Essas formas de relevo em rampa apresentam vertentes com elementos essencialmente côncavos (FUנIмото, 1997).

O Zoneamento Ecológico-Econômico (ZEE) desenvolvido pelo Programa de Gerenciamento Costeiro ${ }^{1}$ (Gerco) para o Litoral Norte do estado do Rio Grande do Sul identificou zonas que apresentam padrões de paisagem semelhantes. Esse zoneamento se caracteriza, também, como um instrumento de gestão que estabelece diretrizes ambientais, permitindo identificar as restrições e potencialidades do uso dos recursos naturais.

$\mathrm{Na}$ área de estudo do presente trabalho, podem-se se identificar algumas das zonas propostas no ZEE inseridas na unidade do Planalto Meridional, bem com a área de ocorrência (em \%) em relação à área total do município estudado pelo Gerco. São elas:

i) Vales: composta pelos vales que entalham a escarpa de falha do Planalto Meridional e que atuam como corredores entre bacias hidrográficas dos rios Maquiné, Três Forquilhas e Mampituba, proporcionando áreas de alimentação, refúgio e deslocamento de espécies vegetais e animais. Essa região vem sofrendo grande pressão de transformação pelo uso agrícola. Essa zona abrange praticamente a totalidade dos municípios de Itati $(90,40 \%)$, Três Forquilhas (87,76\%), Morrinhos do Sul (70,84\%), Mampituba (59,76\%), Maquiné (48,79\%), Três Cachoeiras $(46,61 \%)$ e, parcialmente, os municípios de Terra de Areia (23\%), Osório (8,30\%) e Santo Antônio da Patrulha (sem estimativa).

ii) Nascentes: porção superior dos rios Maquiné e Três Forquilhas, onde ainda encontram-se boas condi- 
ções de biodiversidade, como representantes de espécies endêmicas, sendo a biota sensível ao uso antrópico. Pode-se observar que essa zona abrange parcialmente os municípios de Três Forquilhas (3,94\%), Itati (2,93\%) e Maquiné $(1,47 \%)$.

iii) Araucárias: áreas de campos situados no topo do Planalto Meridional, com predominância de pastagens e ocorrência de araucárias. Essa zona abrange pequenas áreas dos municípios de Três Forquilhas, Maquiné, Itati e Morrinhos do Sul.

iv) Mata Atlântica: zonas Núcleo da Biosfera da Mata Atlântica, definidas por meio de instrumentos legais - unidades de conservação e áreas de preservação permanente do Art. $2^{\circ}$ da Lei № 4771/65. Essa zona abrange os municípios de Maquiné (20,53\%), Mampituba (12,44\%), Itati $(6,65 \%)$ e Morrinhos do Sul (3,24\%).

v) Lagoa do Forno: composta pela Lagoa do Forno e banhados adjacentes, área em que ocorre forte pressão de ocupação pela agricultura irrigada. Abrange basicamente os municípios de Morrinhos do Sul e Dom Pedro de Alcântara.

\section{Unidade da planície de terras baixas costeiras}

A evolução da Planície Costeira encontra-se relacionada com os eventos geotectônicos que ocasionaram a abertura do oceano Atlântico e a formação da bacia Sedimentar de Pelotas, a partir do Jurássico, e que resultaram na ruptura do bloco continental gondwânico e a posterior separação dos continentes africano e sul-americano (ALMEIDA, 1969). Ao longo deste processo foram acumulados, durante a Era Cenozóica, mais de $8.000 \mathrm{~m}$ de sedimentos continentais, transicionais e marinhos. A porção superior desta seqüência sedimentar está exposta na Planície Costeira do Rio Grande do Sul em uma ampla área de terras baixas, ocupadas por um grande sistema lagunar.

Segundo Villwock e Tomazelli (1995), a Planície Costeira do Rio Grande do Sul tem sua formação associada a episódios regressivos e transgressivos dos últimos períodos geológicos (Cenozóico - períodos Terciário e Quaternário). Ao longo desses períodos sucederam-se depósitos continentais e marinhos que originaram uma sequiência de sistemas/barreiras. Estas, sucessivamente, isolaram porções de espaço ocupadas pelo mar que, posteriormente e progressivamente, foram sendo colmatadas, dan- do origem às feições geomorfológicas atuais, bem como à individualização dos sistemas lagunares, que são:

i) Sistema de Leques Aluviais - Este sistema está associado às encostas de terras altas, decorrentes de processos gravitacionais e aluviais de transporte de materiais. Os sedimentos vão desde elúvios e colúvios até depósitos aluviais. Sua formação provavelmente teve início no Terciário e se manteve ao longo de todo o Cenozóico.

ii) Sistema Laguna/Barreira I - Este sistema corresponde ao mais antigo sistema deposicional do tipo laguna/barreira que se formou na Planície Costeira do Rio Grande do Sul. Desenvolveu-se na parte noroeste da planície como resultado de um primeiro evento trans-regressivo Pleistocênico e estendeu-se ao longo de uma faixa com orientação NE-SW, com extensão de 250 km, a partir de acumulação de sedimentos eólicos que ancoraram em altos do embasamento cristalino do Planalto Uruguaio Sulriograndense. Litologicamente é constituído de areias quartzosas avermelhadas, semiconsolidadas com estratificação concordante como uma deposição eólica. Esse corpo sedimentar isolou, ao lado do continente, uma depressão (Sistema Lagunar Guaíba-Gravataí). A posterior sedimentação trazida pelos rios transformou essa depressão em um ambiente de sedimentação fluvial, lagunar e paludal e, posteriormente, importantes depósitos turfáceos se desenvolveram.

iii) Sistema Laguna/Barreira II - Este sistema deposicional corresponde a um segundo evento transregressivo Pleistocênico. Os depósitos eólicos e praiais são preservados somente em alguns lugares da Planície Costeira e suas características litológicas assemelham-se às dos sedimentos do Sistema Laguna/Barreira III. Esse sistema corresponde ao primeiro estágio na evolução da "Barreira Múltipla Complexa", cuja individualização foi representada pela Lagoa dos Patos e pela Lagoa Mirim.

iv) Sistema Laguna/Barreira III - Este é associado a um terceiro evento transregressivo Pleistocênico e suas características sugerem que se desenvolveu principalmente a partir do crescimento lateral de esporões recurvados. Ambientes deposicionais do tipo lagunar, paludal e fluvial encontramse na depressão isolada parcialmente pela Barrei- 
ra II e, principalmente, pela Barreira III. Esse sistema deposicional corresponde à principal barreira responsável pelo isolamento final do Sistema Lagunar Patos Mirim, denominado de Sistema de Barreira Múltipla Complexa.

v) Sistema Laguna/Barreira IV - Este sistema deposicional refere-se ao último evento trans-re- gressivo ocorrido no Holoceno. Estende-se deste a Barreira III por toda a sua borda leste. O máximo de transgressão holocênica ficou marcado a partir dessa regressão, que permitiu o desenvolvimento da Barreira IV. Ela isolou, do lado do continente, um novo sistema lagunar que consiste num rosário de pequenas lagoas.

FIGURA 2 - GEOMORFOLOGIA DA PROVÍNCIA COSTEIRA DO RIO GRANDE DO SUL(FONTE: VILLWOCK E TOMAZELLI, 1985)

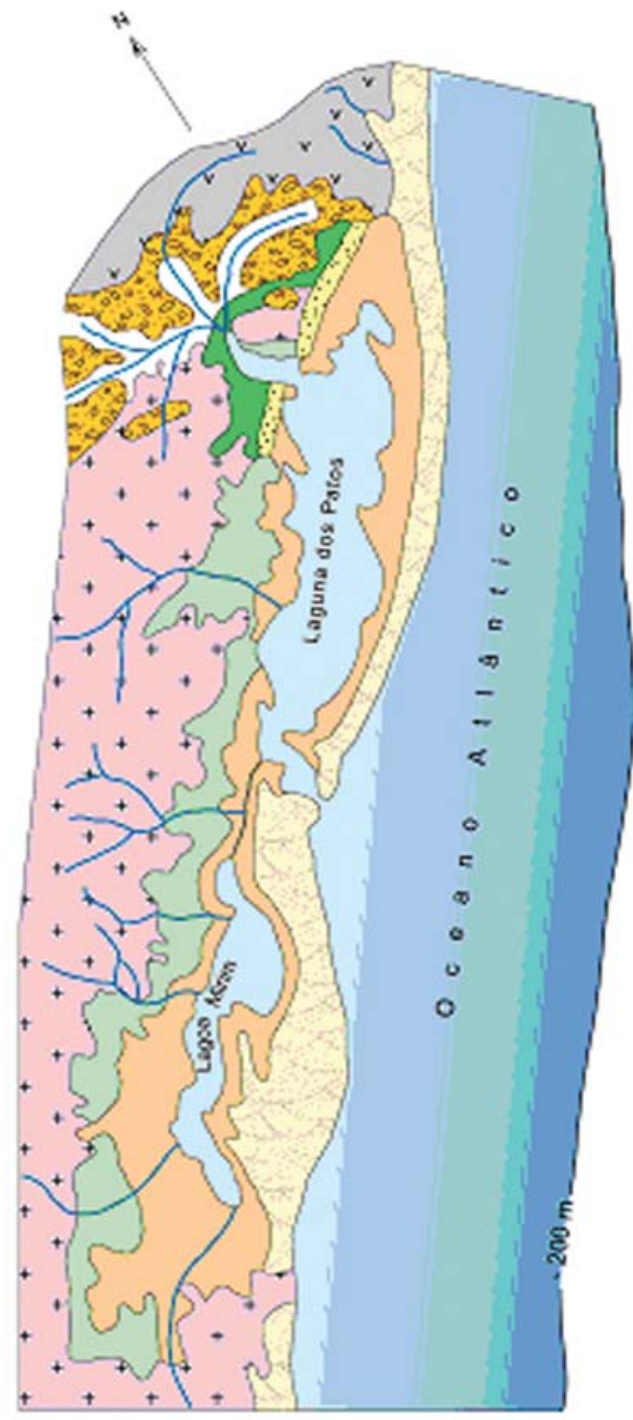

\section{Geomorfologia}

\section{Terras altas}

$+\quad$ Complexo cristalino

Segûẽncias sedimentares da Bacia do Paraná

Seqüència vulcânica

\section{Terras baixas}

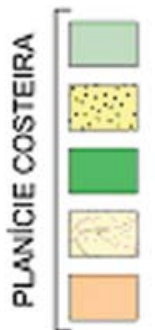

Planicie aluvial interna

Barreira das Lombas

Sistema lagunar Guaíba-Gravataí

Barreira múltipla complexa

Sistema lagunar Patos-Mirim

\section{Plataiorma continental}

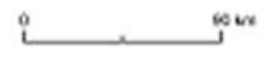


Em decorrência da dinâmica que se processou ao longo desse tempo, a geomorfologia da Planície Costeira do Rio Grande do Sul foi caracterizada por Villwock e Tomazelli (1995). Esta compartimentação pode ser assim descrita (Figura 2):

i) Planície Aluvial Interna: faixa entre o Planalto Uruguaio Sulriograndense e o Sistema Patos-Mirim, formado por terras baixas inclinadas para leste, caracterizadas em termos geomorfológicos pela presença de colinas e terraços.

ii) Barreira das Lombas: faixa com direção NE-SW, com extensão de $250 \mathrm{~km}$ e localizada entre os municípios de Osório e Tapes. Constitui um conjunto de colinas com altitude de aproximadamente $100 \mathrm{~m}$ decorrentes de deposição eólica.

iii) Sistema Lagunar Guaíba-Gravataí: área ocupada pelas bacias hidrográficas desses rios. Caracteriza-se por ser uma área de terras baixas que evoluiu de uma antiga laguna para pântanos, a exemplo do atual Banhado Grande nas Cabeceiras do Rio Gravataí.

iv) Barreira Múltipla Complexa: corresponde à faixa de terra característica do Litoral Norte do Estado do Rio Grande do Sul, entre o Planalto Meridional e o Oceano Atlântico, que, ao sul, foi responsável pelo isolamento das Lagunas Patos e Mirim. Este compartimento consiste em uma sucessão de terraços, bastante planos, intercalados com depressões, as quais foram ocupadas por lagunas, lagoas e pântanos em diferentes estágios evolutivos. O conjunto é composto por sistemas do tipo laguna/barreira, desenvolvidos durante os três últimos grandes ciclos de variação do nível do mar. Depósitos praiais e eólicos transicionam e se interdigitam com depósitos lagunares, lacustres, paludiais, fluviais e deltaicos.

v) Sistema Lagunar Patos-Mirim: corresponde ao primeiro estágio de formação da Barreira Múltipla Complexa. Durante sua evolução, promoveu a formação de terraços, cristas de praias, pântanos e pontais arenosos.

Na unidade da Planície de Terras Baixas Costeiras, mais precisamente no compartimento identificado, por Villwock e Tomazelli (1995), com Barreira Múltipla-Complexa, podem-se identificar algumas das zonas propostas no Zoneamento Ecológico-Econômico (ZEE) do Programa de Gerenciamento Costeiro (Gerco), assim com a área de ocorrência (em \%) com relação à área total do município. São elas:

- Dunas: referem-se a locais dispersos ao longo da faixa costeira que apresentam a melhor situação de conservação, constituindo a última oportunidade no Litoral Norte de preservar a seqüência natural e característica de ambientes, abrangendo, de forma contínua, o sistema praial, o campo de dunas e o sistema de lagoas costeiras. Destaca-se a importância da fauna associada, em bom estado de conservação, garantida pela ocupação humana ainda pouco significativa. Destaca-se a ocorrência de dunas preservadas nos municípios de Cidreira (38\%), Tramandaí (34\%) e Torres (11\%).

- Balneários: correspondem a uma ocupação urbana contínua em faixa longitudinal ao oceano. Caracterizam-se pela ocorrência de processos erosivos e de deposição eólica de sedimentos, formada pelas dunas frontais, dunas vegetadas monticulares, corredores de alimentação eólica, dunas livres, lençóis eólicos e planícies interdunas. Pode-se observar que essa zona abrange significativamente os municípios de Imbé (58\%), Balneário Pinhal (28\%), Capão da Canoa (23\%), Arroio do Sal (21\%), Xangri-lá (21\%), e parcialmente os municípios de Tramandaí (17\%), Cidreira (10\%), Torres (7\%), Osório $(5,34 \%)$ e Terra de Areia (2\%).

- Campos: referem-se à zona de transição entre o sistema de lagoas e a faixa arenosa da zona de balneários, onde se intercalam campos secos arenosos e banhados, com predomínio de atividades agropecuárias. Abrangem significativamente os municípios de Arroio do Sal (54\%), Capão da Canoa (52\%), Xangri-lá (37\%) e, parcialmente, os municípios Torres (9\%), Terra de Areia (5\%) e Osório (1\%).

- Áreas Úmidas Novas: correspondem às áreas de dunas de retrabalhamento eólico, lagos e pântanos, com paleosolos, lamas orgânicas e turfas, onde ocorrem alterações significativas provocadas pelos usos de mineração, urbanização, lavouras, pastagens e reflorestamento. Essa zona é representativa nos municípios de Torres (44\%), Balneário Pinhal (44\%), Tramandaí (35\%), Cidreira (31\%), Osório (25,57\%), Dom Pedro de Alcântara (16\%), 
Morrinhos do Sul (7,6\%) Terra de Areia (9\%), Três Cachoeiras (5,45\%) e Mampituba (4,78\%).

- Lagoas: zona de lagoas interligadas, consistindo em corredores de fauna e flora, apresentando áreas importantes de reprodução e/ou criação de peixe, de espécies endêmicas e em extinção. São corpos d'água (de até $3,8 \mathrm{~m}$ de profundidade), ainda em sua maioria com boa qualidade, porém com grande pressão de ocupação urbana em seu entorno. Praticamente a maioria dos municípios da região do Litoral Norte tem lagoas em seu território, dos quais se destacam Dom Pedro de Alcântara (43\%), Imbé (42\%), Osório (40,78\%), Xangri-lá (47\%) e Três Cachoeiras $(44,23 \%)$, Maquiné (28,56\%), Arroio do Sal (25\%), Capão da Canoa (25\%). Os demais municípios são Terra de Areia (16\%), Cidreira (12\%), Torres (12\%), Tramandaí (5\%), Três Forquilhas $(0,50 \%)$ e Mampituba $(0,50 \%)$.

- Banhados: áreas úmidas, entre lagoas, formando lagoas e pântanos com ocupação antrópica por agropecuária e sítios de lazer. Abrangem os municípios de Terra de Areia (39\%), Cidreira (38\%), Tramandaí (34\%), Dom Pedro de Alcântara (26\%), Osório (12,4\%), Torres (11\%), Morrinhos do Sul $(6,3 \%)$, Três Cachoeiras $(3,42 \%)$ e Mampituba (0,30\%).

- Áreas Úmidas Antigas: uso rural extensivo, presença de turfeiras e banhados, com resquícios importantes de mata nativa, envolvendo as lagoas que restaram. Abrangem os municípios de Balneário Pinhal (9\%), Cidreira (7\%), Tramandaí (5\%) e Osório (5\%).

\section{Caracterização socioeconômica do Litoral Norte do Rio Grande do Sul}

A caracterização socioeconômica realizada procura traçar o perfil dos municípios do Litoral Norte do Rio Grande do Sul, a partir de indicadores de desenvolvimento social e econômico da região. Para tanto, foram utilizados o Índice de Desenvolvimento Socioeconômico (Idese) ${ }^{2}$ o Valor Adicionado Bruto $(\mathrm{VAB})^{3}$ e a infra-estrutura sanitária (abastecimento de água, saneamento e coleta de lixo).

No âmbito regional, pode-se comparar o Idese do Conselho Regional de Desenvolvimento (Corede) do Litoral com os demais Coredes e com o total do Estado em dois momentos: 1991 e 2000, conforme se pode observar nas Tabelas 1 e 2. Comparando-se os dados do Idese de $1991 \mathrm{e}$ de 2000, constata-se uma evolução no desenvolvimento do Estado, passando de um índice de 0,688, em 1991, para $0,751 \mathrm{em} 2000$. Esses resultados apontam para um grau de desenvolvimento médio no estado do Rio Grande do Sul. ${ }^{4}$

Percebe-se o aumento no desenvolvimento de algumas regiões, mas esse crescimento não é homogêneo. As menores evoluções ocorreram nos Coredes: Campanha, Litoral e Sul. O menor ritmo de desenvolvimento dessas regiões ocasionou uma queda nas suas posições em relação às demais, passando o Corede da Campanha de quarto lugar, em 1991, para sexto em 2000; o Litoral, de décimo segundo para vigésimo, e o Sul, de quinto para décimo, nos mesmos anos.

Quando se examina a evolução do Idese por blocos, verifica-se que todos apresentaram crescimento entre 1991 e 2000. O bloco que obteve maior acréscimo foi o de Condições de Saneamento, passando o seu indicador de 0,457 em 1991 (baixo desenvolvimento) para 0,562 em 2000 (médio desenvolvimento). Mesmo assim, esse bloco ainda permanece como o de menor grau de desenvolvimento relativamente aos demais. Contudo, o indicador do Litoral continua com baixo desenvolvimento, sendo de 0,352 em 1991 e 0,420 em 2000.

O bloco da Educação foi o segundo de maior crescimento entre os anos de 1991 e 2000, evoluindo o seu índice de 0,765 (médio desenvolvimento) para 0,834 (alto desenvolvimento). Em 1991, todos os Coredes apresentavam um índice médio de desenvolvimento, e, em 2000, exceto o Corede Centro-Sul $(0,796)$, todos os demais se classificaram com alto desenvolvimento.

\footnotetext{
O Idese é um índice estadual, resultado da agregação, com a mesma ponderação $(0,25)$, de quatro blocos de indicadores: educação, renda, saúde e saneamento e domicílio.

O Valor Adicionado Bruto (VAB) a preço básico é a diferença entre o valor bruto da produção, medido a preços do produtor, sem incluir os impostos que incidem sobre os produtos do setor, e o consumo intermediário, mensurado a preços de mercado.

4 Os municípios foram classificados pelo Idese em três grandes grupos: baixo desenvolvimento (índices até 0,499 ), médio desenvolvimento (entre 0,500 e 0,799 ) e alto desenvolvimento (maiores que 0,800).
} 


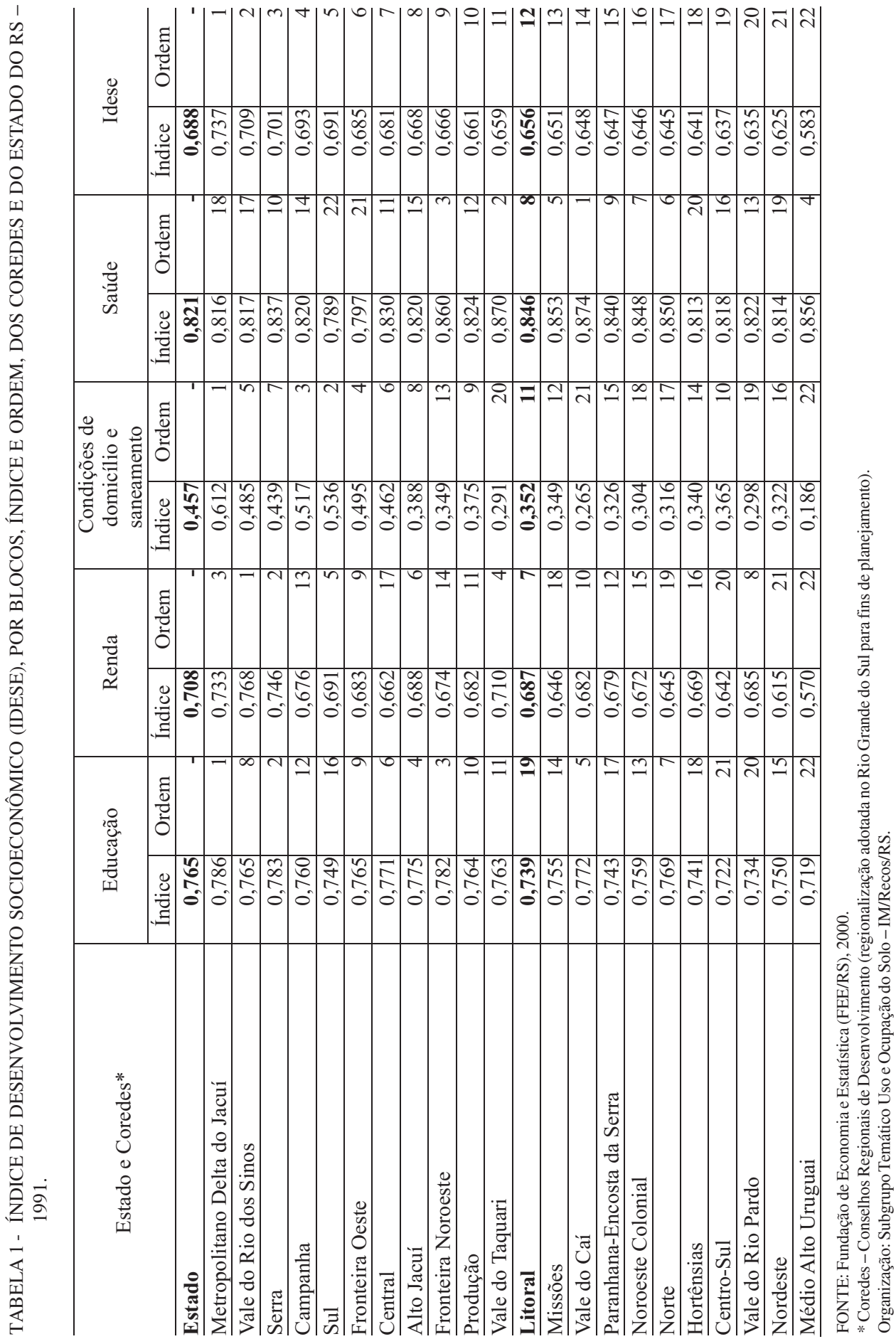




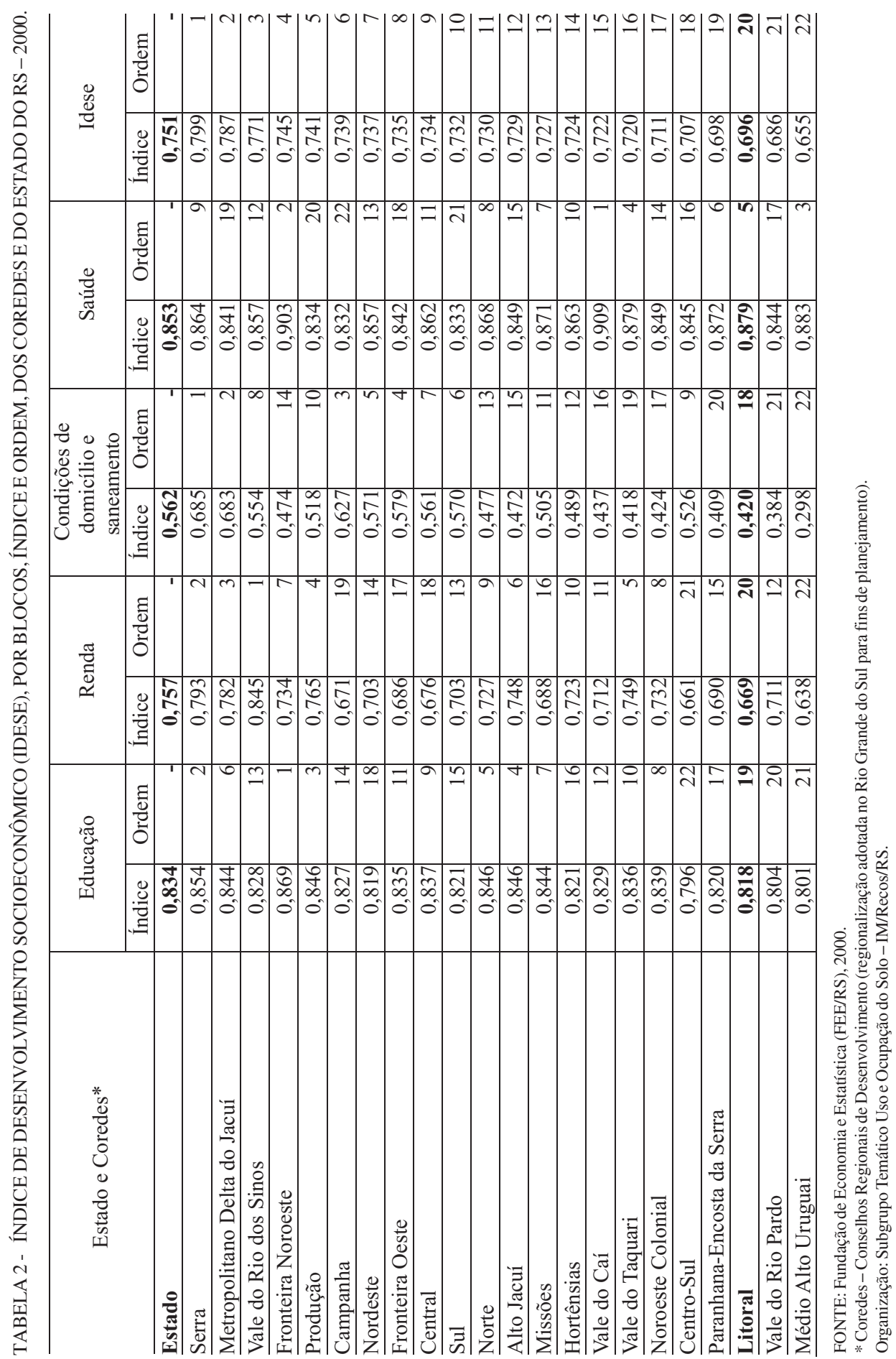


O bloco Renda manteve-se estável em relação ao seu médio desenvolvimento para o estado, verificando-se a passagem de seu indicador de 0,708 para 0,757 em 2000 . Neste bloco verificou-se a redução no índice para dois Coredes entre os anos de 1991 e 2000, fato este observado no Litoral, que passou de 0,687 para 0,669, e no da Campanha, que passou de 0,676 para 0,671. Com isso, o Litoral, que ocupava a sétima posição em 1991, passou a ocupar a vigésima em 2000, e a Campanha teve sua posição alterada da décima terceira para a décima nona.

O bloco da Saúde foi o que apresentou o menor incremento no período, mas, tanto em 1991 como em 2000, os índices enquadravam-se como de alto desenvolvimento, respectivamente, 0,821 e 0,853 .

O Idese geral dos municípios da área de estudo apresenta-se com médio desenvolvimento, conforme a Tabela 3. De um modo geral, as variáveis Educação e Saúde apresentam alto desenvolvimento, mas a variável de Saneamento e Domicílio apresenta baixo desenvolvimento, sendo responsável pela redução geral da média do Idese.

O indicador Educação, conforme a Tabela 4, apresenta alto índice de desenvolvimento na grande maioria dos municípios. Somente Caraá, Maquiné e Três Forquilhas apresentam médio desenvolvimento, municípios localiza-

TABELA 3 - ÍNDICE DE DESENVOLVIMENTO SOCIOECONÔMICO PARA OS MUNICÍPIOS DE LITORAL NORTE DO RS (IDESE)

\begin{tabular}{l|c|c}
\hline \multirow{2}{*}{ Municípios } & \multicolumn{2}{|c}{ Idese Geral } \\
\cline { 2 - 3 } & índice & ordem \\
\hline Arroio do Sal & 0,646 & 304 \\
\hline Balneário Pinhal & 0,633 & 339 \\
\hline Capão da Canoa & 0,731 & 92 \\
\hline Capivari do Sul & 0,694 & 180 \\
\hline Caraá & 0,540 & 461 \\
\hline Cidreira & 0,711 & 134 \\
\hline D.Pedro de Alcântara & 0,626 & 350 \\
\hline Imbé & 0,742 & 70 \\
\hline Itati $*$ & & \\
\hline Mampituba & 0,552 & 453 \\
\hline Maquiné & 0,570 & 437 \\
\hline Morrinhos do Sul & 0,594 & 407 \\
\hline Osório & 0,744 & 68 \\
\hline Palmares do Sul & 0,644 & 312 \\
\hline Sto.Antônio da Patrulha & 0,656 & 277 \\
\hline Terra de Areia & 0,622 & 355 \\
\hline Torres & 0,756 & 42 \\
\hline Tramandaí & 0,728 & 93 \\
\hline Três Cachoeiras & 0,662 & 258 \\
\hline Três Forquilhas & 0,561 & 445 \\
\hline Xangri-lá & 0,719 & 113 \\
\hline Litoral Norte** & $\mathbf{0 , 6 9 6}$ & $\mathbf{2 0}$ \\
\hline Rio Grande do Sul & $\mathbf{0 , 7 5 1}$ & \\
\hline
\end{tabular}

FONTE: Fundação de Economia e Estatística (FEE/RS), 2000.

* Município emancipado em 1996.

** Os dados referentes ao Litoral Norte tiveram como critério os Conselhos Regionais de Desenvolvimento (Coredes): regionalização adotada no Rio Grande do Sul para fins de planejamento, no caso incluindo o município de Mostardas.

Organização: Subgrupo Temático Uso e Ocupação do Solo - IM/Recos/RS 
dos na escarpa do planalto e com perfil rural. Este indicador é composto pelas seguintes variáveis: taxa de evasão no ensino fundamental, taxa de reprovação no ensino fundamental, taxa de atendimento no ensino médio e taxa de analfabetismo de pessoas de 15 anos e mais idade.

A única variável que apresenta em todos os municípios baixo desenvolvimento é a taxa de atendimento, demonstrando a falta de estabelecimentos de ensino médio na região. O restante das taxas apresenta alto desenvolvimento em todos os municípios da área de estudo.

A região conta com 106 estabelecimentos de ensino na rede estadual, 186 na rede municipal e apenas 32 estabelecimentos de ensino na rede particular. No entanto, deste número de estabelecimentos de ensino, apenas 26 atendem ao ensino médio, havendo necessidade de deslocamen- tos de estudantes para fora da região. Portanto, é necessário investir no ensino médio, tanto no que se refere ao número de vagas disponíveis na rede pública quanto na qualificação do quadro de professores e técnicos administrativos.

Com relação ao indicador Renda temos os municípios de Caraá, Mampituba e Três Forquilhas, todos localizados na escarpa do planalto, com baixos índices de desenvolvimento, ou seja, com 0,427, 0,463 e 0,439 respectivamente; os demais apresentam médio desenvolvimento. $\mathrm{O}$ indicador Renda é composto pelas seguintes variáveis: geração (Produto Interno Bruto per capita) e apropriação (Valor Adicionado Bruto per capita do comércio, alojamento e alimentação).

A geração de renda compreende médio desenvolvimento, com exceção de Capivari do Sul $(0,840)$ com alto

TABELA 4 - ÍNDICE DE DESENVOLVIMENTO SOCIOECONÔMICO SEGUNDO O INDICADOR EDUCAÇÃO

\begin{tabular}{|c|c|c|c|c|c|c|c|c|c|c|}
\hline \multirow[t]{2}{*}{ Municípios } & \multicolumn{2}{|c|}{$\begin{array}{l}\text { Taxa de } \\
\text { evasão }\end{array}$} & \multicolumn{2}{|c|}{$\begin{array}{c}\text { Taxa de } \\
\text { reprovação }\end{array}$} & \multicolumn{2}{|c|}{$\begin{array}{c}\text { Taxa de } \\
\text { atendimento }\end{array}$} & \multicolumn{2}{|c|}{$\begin{array}{c}\text { Taxa de } \\
\text { analfabetismo }\end{array}$} & \multicolumn{2}{|c|}{$\begin{array}{c}\text { Índice geral da } \\
\text { educação }\end{array}$} \\
\hline & índice & ordem & índice & ordem & índice & ordem & índice & ordem & índice & ordem \\
\hline Arroio do Sal & 0,964 & 267 & 0,886 & 179 & 0,485 & 164 & 0,933 & 159 & 0,842 & 155 \\
\hline Balneário Pinhal & 0,939 & 430 & 0,896 & 133 & 0,349 & 376 & 0,928 & 179 & 0,808 & 308 \\
\hline Capão da Canoa & 0,946 & 394 & 0,840 & 362 & 0,411 & 292 & 0,937 & 133 & 0,815 & 269 \\
\hline Capivari do sul & 0,954 & 339 & 0,936 & 34 & 0,436 & 206 & 0,910 & 255 & 0,837 & 179 \\
\hline Caraá & 0,965 & 257 & 0,907 & 93 & 0,403 & 307 & 0,819 & 456 & 0,790 & 376 \\
\hline Cidreira & 0,944 & 411 & 0,875 & 218 & 0,349 & 375 & 0,951 & 72 & 0,813 & 277 \\
\hline D.Pedro de Alcântara & 0,977 & 155 & 0,853 & 306 & 0,474 & 183 & 0,894 & 308 & 0,822 & 234 \\
\hline Imbé & 0,985 & 83 & 0,869 & 246 & 0,483 & 168 & 0,955 & 61 & 0,851 & 109 \\
\hline \multicolumn{11}{|l|}{ Itati * } \\
\hline Mampituba & 0,980 & 119 & 0,888 & 171 & 0,474 & 182 & 0,833 & 446 & 0,809 & 305 \\
\hline Maquiné & 0,962 & 281 & 0,805 & 437 & 0,349 & 377 & 0,881 & 345 & 0,780 & 404 \\
\hline Morrinhos do Sul & 0,976 & 173 & 0,940 & 25 & 0,350 & 373 & 0,883 & 339 & 0,811 & 289 \\
\hline Osório & 0,967 & 245 & 0,844 & 0,5 & 0,491 & 159 & 0,935 & 143 & 0,836 & 183 \\
\hline Palmares do Sul & 0,928 & 448 & 0,854 & 301 & 0,463 & 207 & 0,885 & 336 & 0,805 & 326 \\
\hline Sto.Antônio da Patrulha & 0,959 & 303 & 0,899 & 125 & 0,403 & 308 & 0,870 & 382 & 0,805 & 329 \\
\hline Terra de Areia & 0,956 & 321 & 0,892 & 152 & 0,392 & 326 & 0,882 & 344 & 0,804 & 330 \\
\hline Torres & 0,979 & 128 & 0,847 & 344 & 0,474 & 184 & 0,937 & 129 & 0,837 & 177 \\
\hline Tramandaí & 0,950 & 367 & 0,852 & 314 & 0,405 & 305 & 0,937 & 128 & 0,817 & 256 \\
\hline Três Cachoeiras & 0,958 & 313 & 0,899 & 124 & 0,447 & 241 & 0,910 & 254 & 0,827 & 225 \\
\hline Três Forquilhas & 0,976 & 163 & 0,837 & 371 & 0,210 & 454 & 0,827 & 452 & 0,743 & 455 \\
\hline Xangri-lá & 0,963 & 278 & 0,848 & 343 & 0,460 & 215 & 0,949 & 77 & 0,834 & 191 \\
\hline Litoral Norte** & & & & & & & & & 0,818 & 19 \\
\hline Rio Grande do Sul & 0,958 & & 0,856 & & 0,485 & & 0,933 & & $\mathbf{0 , 8 3 4}$ & \\
\hline
\end{tabular}

FONTE: Fundação de Economia e Estatística (FEE/RS), 2000.

* Município emancipado em 1996.

** Os dados referentes ao Litoral Norte tiveram como critério os Coredes, no caso incluindo o município de Mostardas.

Organização: Subgrupo Temático Uso e Ocupação do Solo - IM/Recos/RS. 
índice de desenvolvimento. Já a apropriação da renda apresenta uma situação pouco animadora nos municípios de: Balneário Pinhal, Caraá, Mampituba, Maquiné, Morrinhos do Sul, Palmares do Sul e Três Forquilhas, todos com baixo desenvolvimento. Os demais municípios não passam de médio desenvolvimento, como se verifica na Tabela 5.

Com exceção de Balneário Pinhal e Palmares do Sul, os demais municípios com baixo desenvolvimento quanto à apropriação de renda têm perfil eminentemente rural.

O indicador de Saneamento e Domicílio é composto das seguintes variáveis: proporção de domicílios abastecidos com água tratada, proporção de domicílios atendidos pela rede de esgoto geral ou pluvial e média de moradores por domicílio.
A situação é precária no que se refere ao abastecimento de esgoto, pois todos os municípios do Litoral Norte do Rio Grande do Sul apresentam baixo desenvolvimento. Em relação ao abastecimento de água tratada, o quadro difere, apresentando treze municípios com baixo desenvolvimento, em sua maioria municípios com perfil rural. Osório e Torres apresentam médio desenvolvimento. Com alto desenvolvimento, temos: Capão da Canoa, Cidreira, Imbé, Tramandaí e Xangri-lá.

O índice geral de Saneamento e Domicílio é preocupante: apenas sete municípios apresentam médio desenvolvimento. São eles: Capão da Canoa, Cidreira, Imbé, Osório, Torres, Tramandaí e Xangri-lá. Os demais apresentam baixo índice de desenvolvimento. Vale res-

TABELA 5 - ÍNDICE DE DESENVOLVIMENTO SOCIOECONÔMICO SEGUNDO O INDICADOR RENDA

\begin{tabular}{|c|c|c|c|c|c|c|}
\hline \multirow{2}{*}{ Municípios } & \multicolumn{2}{|c|}{ Geração } & \multicolumn{2}{|c|}{ Apropriação } & \multicolumn{2}{|c|}{ Índice geral de renda } \\
\hline & índice & ordem & índice & ordem & índice & ordem \\
\hline Arroio do Sal & 0,692 & 387 & 0,612 & 172 & 0,652 & 211 \\
\hline Balneário Pinhal & 0,657 & 444 & 0,498 & 277 & 0,578 & 353 \\
\hline Capão da Canoa & 0,660 & 439 & 0,690 & 103 & 0,675 & 170 \\
\hline Capivari do sul & 0,840 & 38 & 0,687 & 104 & 0,764 & 55 \\
\hline Caraá & 0,640 & 461 & 0,213 & 454 & 0,427 & 462 \\
\hline Cidreira & 0,650 & 450 & 0,585 & 193 & 0,617 & 283 \\
\hline D.Pedro de Alcântara & 0,646 & 455 & 0,520 & 252 & 0,583 & 340 \\
\hline Imbé & 0,699 & 360 & 0,695 & 91 & 0,697 & 131 \\
\hline \multicolumn{7}{|l|}{ Itati * } \\
\hline Mampituba & 0,734 & 244 & 0,192 & 459 & 0,463 & 453 \\
\hline Maquiné & 0,629 & 464 & 0,499 & 276 & 0,564 & 375 \\
\hline Morrinhos do Sul & 0,682 & 401 & 0,317 & 423 & 0,500 & 435 \\
\hline Osório & 0,689 & 390 & 0,771 & 39 & 0,730 & 88 \\
\hline Palmares do Sul & 0,740 & 227 & 0,495 & 280 & 0,618 & 282 \\
\hline Sto.Antônio da Patrulha & 0,695 & 379 & 0,600 & 182 & 0,648 & 223 \\
\hline Terra de Areia & 0,630 & 463 & 0,524 & 248 & 0,577 & 356 \\
\hline Torres & 0,648 & 453 & 0,721 & 65 & 0,685 & 157 \\
\hline Tramandaí & 0,646 & 454 & 0,684 & 106 & 0,665 & 186 \\
\hline Três Cachoeiras & 0,655 & 447 & 0,613 & 171 & 0,634 & 253 \\
\hline Três Forquilhas & 0,666 & 433 & 0,212 & 455 & 0,439 & 459 \\
\hline Xangri-lá & 0,720 & 295 & 0,618 & 164 & 0,669 & 179 \\
\hline Litoral Norte** & & & & & 0,669 & 20 \\
\hline Rio Grande do Sul & 0,766 & & 0,748 & & 0,757 & \\
\hline
\end{tabular}

FONTE: Fundação de Economia e Estatística (FEE/RS), 2000.

* Município emancipado em 1996.

** Os dados referentes ao Litoral Norte tiveram como critério os Coredes, no caso incluindo o município de Mostardas.

Organização: Grupo Uso e Ocupação do Solo - IM - Recos/RS. 


\section{TABELA 6 - ÍNDICE DE DESENVOLVIMENTO SOCIOECONÔMICO SEGUNDO O INDICADOR SANEAMENTO E DOMICÍLIOS}

\begin{tabular}{|c|c|c|c|c|c|c|c|c|}
\hline \multirow[t]{2}{*}{ Municípios } & \multicolumn{2}{|c|}{$\begin{array}{l}\text { Abastecimento de água } \\
\text { (rede geral) }\end{array}$} & \multicolumn{2}{|c|}{$\begin{array}{l}\text { Abastecimento de esgoto } \\
\text { (rede geral ou pluvial) }\end{array}$} & \multicolumn{2}{|c|}{$\begin{array}{l}\text { Média de moradores } \\
\text { por domicílio }\end{array}$} & \multicolumn{2}{|c|}{$\begin{array}{l}\text { Índice geral de saneamento e } \\
\text { domicílios }\end{array}$} \\
\hline & índice & ordem & índice & ordem & índice & ordem & índice & ordem \\
\hline Arroio do Sal & 0,296 & 369 & 0,004 & 309 & 0,567 & 25 & 0,206 & 371 \\
\hline Balneário Pinhal & 0,445 & 303 & 0,003 & 323 & 0,550 & 72 & 0,279 & 310 \\
\hline Capão da Canoa & 0,915 & 27 & 0,156 & 98 & 0,513 & 244 & 0,571 & 56 \\
\hline Capivari do sul & 0,459 & 291 & 0,022 & 213 & 0,541 & 104 & 0,292 & 300 \\
\hline Caraá & 0,008 & 438 & 0,002 & 363 & 0,554 & 54 & 0,060 & 432 \\
\hline Cidreira & 0,901 & 35 & 0,018 & 225 & 0,565 & 28 & 0,514 & 91 \\
\hline D.Pedro de Alcântara & 0,283 & 374 & 0,050 & 176 & 0,571 & 21 & 0,219 & 361 \\
\hline Imbé & 0,953 & 8 & 0,012 & 247 & 0,541 & 106 & 0,535 & 77 \\
\hline \multicolumn{9}{|l|}{ Itati * } \\
\hline Mampituba & 0,053 & 420 & 0,001 & 382 & 0,527 & 169 & 0,080 & 422 \\
\hline Maquiné & 0,010 & 435 & 0,001 & 392 & 0,532 & 145 & 0,058 & 435 \\
\hline Morrinhos do Sul & 0,307 & 365 & 0,001 & 390 & 0,547 & 85 & 0,209 & 370 \\
\hline Osório & 0,799 & 101 & 0,184 & 86 & 0,535 & 132 & 0,527 & 81 \\
\hline Palmares do Sul & 0,387 & 336 & 0,017 & 230 & 0,551 & 69 & 0,255 & 336 \\
\hline Sto.Antônio da Patrulha & 0,460 & 290 & 0,074 & 160 & 0,558 & 42 & 0,315 & 281 \\
\hline Terra de Areia & 0,398 & 330 & 0,004 & 294 & 0,528 & 168 & 0,254 & 339 \\
\hline Torres & 0,797 & 102 & 0,400 & 26 & 0,550 & 71 & 0,614 & 36 \\
\hline Tramandaí & 0,888 & 48 & 0,149 & 102 & 0,526 & 179 & 0,556 & 66 \\
\hline Três Cachoeiras & 0,280 & 376 & 0,137 & 110 & 0,530 & 150 & 0,248 & 342 \\
\hline Três Forquilhas & 0,225 & 395 & 0 & 437 & 0,545 & 94 & 0,167 & 394 \\
\hline Xangri-lá & 0,890 & 46 & 0,029 & 205 & 0,497 & 312 & 0,506 & 97 \\
\hline Litoral Norte** & & & & & & & 0,420 & 18 \\
\hline Rio Grande do Sul & 0,797 & & 0,274 & & 0,535 & & 0,562 & \\
\hline
\end{tabular}

FONTE: Fundação de Economia e Estatística (FEE/RS), 2000.

* Município emancipado em 1996.

** Os dados referentes ao Litoral Norte tiveram como critério os Coredes, no caso incluindo o município de Mostardas.

Organização: Subgrupo Temático Uso e Ocupação do Solo - IM/ Recos/RS.

saltar que a situação verificada pelo índice só não é mais preocupante graças ao médio desenvolvimento dos municípios em relação à média de moradores por domicílio, como verificamos nos dados da Tabela 6.

Dessa maneira, pode-se sintetizar afirmando que a variável de saneamento e domicílio é a de maior carência na região, principalmente nos municípios de perfil rural.

O indicador Saúde apresenta alto desenvolvimento nos municípios da região, conforme verificamos na Tabela 7. As variáveis consideradas são: baixo peso ao nascer, mortalidade de menores de cinco anos e expectativa de vida. Somente esta última apresenta, além de altos, médios índices de desenvolvimento, verificados nos seguintes municípios: Balneário Pinhal, Capão da Canoa, Cidreira, Imbé,
Mampituba, Maquiné, Morrinhos do Sul, Santo Antônio da Patrulha, Terra de Areia e Tramandaí. Contudo, o indicador de condições de saúde não contempla variáveis como número de hospitais, leitos e médicos, ou seja, não trata da infra-estrutura da saúde. No Litoral Norte, a infra-estrutura de saúde é precária, havendo apenas oito hospitais na região, com 568 leitos para uma população de 268.698 habitantes, enquanto o padrão aceitável, segundo a Organização Mundial de Saúde, seria de 4,5 leitos para cada mil habitantes. Para atender a região seriam necessários 1209 leitos, ou seja, o dobro do número atual de leitos existentes nos hospitais da região.

Conforme se pode observar, a região do Litoral Norte tem um Idese de médio desenvolvimento, contudo, para a 
TABELA 7 - ÍNDICE DE DESENVOLVIMENTO SOCIOECONÔMICO SEGUNDO O INDICADOR SAÚDE

\begin{tabular}{|c|c|c|c|c|c|c|c|c|}
\hline \multirow[t]{2}{*}{ Municípios } & \multicolumn{2}{|c|}{ Baixo peso ao nascer } & \multicolumn{2}{|c|}{ Mortalidade $<$ de 5 anos } & \multicolumn{2}{|c|}{ Expectativa de vida } & \multicolumn{2}{|c|}{ Índice geral de saúde } \\
\hline & índice & ordem & índice & ordem & índice & ordem & índice & ordem \\
\hline Arroio do Sal & 0,875 & 131 & 0,961 & 192 & 0,818 & 143 & 0,885 & 99 \\
\hline Balneário Pinhal & 0,875 & 132 & 0,961 & 193 & 0,760 & 345 & 0,866 & 227 \\
\hline Capão da Canoa & 0,864 & 179 & 0,964 & 152 & 0,760 & 344 & 0,863 & 249 \\
\hline Capivari do sul & 0,875 & 133 & 0,961 & 194 & 0,811 & 172 & 0,883 & $\overline{114}$ \\
\hline Caraá & 0,875 & 134 & 0,961 & 195 & 0,817 & 147 & 0,885 & 106 \\
\hline Cidreira & 0,921 & 34 & 0,984 & 18 & 0,792 & 244 & 0,899 & $\overline{40}$ \\
\hline D.Pedro de Alcântara & 0,875 & 135 & 0,961 & 196 & 0,806 & 194 & 0,881 & 125 \\
\hline Imbé & 0,912 & 50 & 0,953 & 316 & 0,792 & 247 & 0,885 & 93 \\
\hline \multicolumn{9}{|l|}{ Itati * } \\
\hline Mampituba & 0,875 & 136 & 0,961 & 197 & 0,736 & 397 & 0,857 & 280 \\
\hline Maquiné & 0,875 & 137 & 0,961 & 198 & 0,792 & 246 & 0,876 & 164 \\
\hline Morrinhos do Sul & 0,875 & 138 & 0,961 & 199 & 0,729 & 414 & 0,855 & 294 \\
\hline Osório & 0,811 & 316 & 0,969 & 90 & 0,865 & 7 & 0,882 & 121 \\
\hline Palmares do Sul & 0,882 & 118 & 0,990 & 9 & 0,817 & 145 & 0,896 & 47 \\
\hline Sto.Antônio da Patrulha & 0,800 & 353 & 0,972 & 75 & 0,792 & 245 & 0,854 & 309 \\
\hline Terra de Areia & 0,826 & 285 & 0,942 & 402 & 0,795 & 231 & 0,855 & 308 \\
\hline Torres & 0,904 & 74 & 0,949 & 361 & 0,817 & 149 & 0,890 & 73 \\
\hline Tramandaí & 0,888 & 111 & 0,941 & 414 & 0,792 & 242 & 0,874 & 180 \\
\hline Três Cachoeiras & 1 & 3 & 1 & 1 & 0,180 & 142 & 0,939 & $\overline{1}$ \\
\hline Três Forquilhas & 0,875 & 140 & 0,961 & 201 & 0,850 & 27 & 0,895 & 52 \\
\hline Xangri-lá & 0,797 & 362 & 0,984 & 17 & 0,817 & 146 & 0,866 & 220 \\
\hline Litoral Norte** & & & & & & & 0,879 & 5 \\
\hline Rio Grande do Sul & 0,817 & & 0,956 & & 0,784 & & 0,853 & \\
\hline
\end{tabular}

FONTE: Fundação de Economia e Estatística (FEE/RS), 2000.

* Município emancipado em 1996.

** Os dados referentes ao Litoral Norte tiveram como critério os Coredes, no caso incluindo o município de Mostardas.

Organização: Grupo Uso e Ocupação do Solo - IM/Recos/RS.

melhor visualização do referido índice, elaborou-se a Figura 3. Esta figura apresenta os municípios do Litoral Norte em faixas de 0,500 a 0,599; 0,600 a 0,699 e 0,700 a 0,799, ou seja, dentro do médio desenvolvimento apresentado, podemos reagrupar os municípios do Litoral Norte em baixo, médio e alto desenvolvimento.

O Idese geral do Litoral Norte do Rio Grande do Sul é de 0,696, inferior ao índice do estado, que é de 0,751. O índice da região só supera o do estado no indicador de Saúde; nos demais indicadores, Educação, Renda e Saneamento e Domicílio, o Litoral Norte apresenta índices inferiores ao do Estado.

Após as análises feitas sobre o Idese, é importante ressaltar a necessidade de grandes investimentos no setor de abastecimento de água e esgoto, pois, não havendo es- tes investimentos, a qualidade ambiental do Litoral Norte ficará cada vez mais comprometida.

\section{Valor Adicionado Bruto}

Os dados relativos ao Valor Adicionado Bruto (VAB) dos municípios do Litoral Norte abrangeram três setores: a) agropecuário, que compreende as atividades relativas à agricultura, pecuária, silvicultura e exploração florestal; b) indústria, que compreende a indústria extrativa mineral e a de transformação, juntamente com eletricidade, gás, água e construção; e c) serviços, que se divide em comércio e demais serviços. 
FIGURA 3 - LITORAL NORTE DO RIO GRANDE DO SUL SEGUNDO IDESE (FONTE: FUNDAÇÃO DE ECONOMIAE ESTATÍSTICA FEE/RS, 2000)

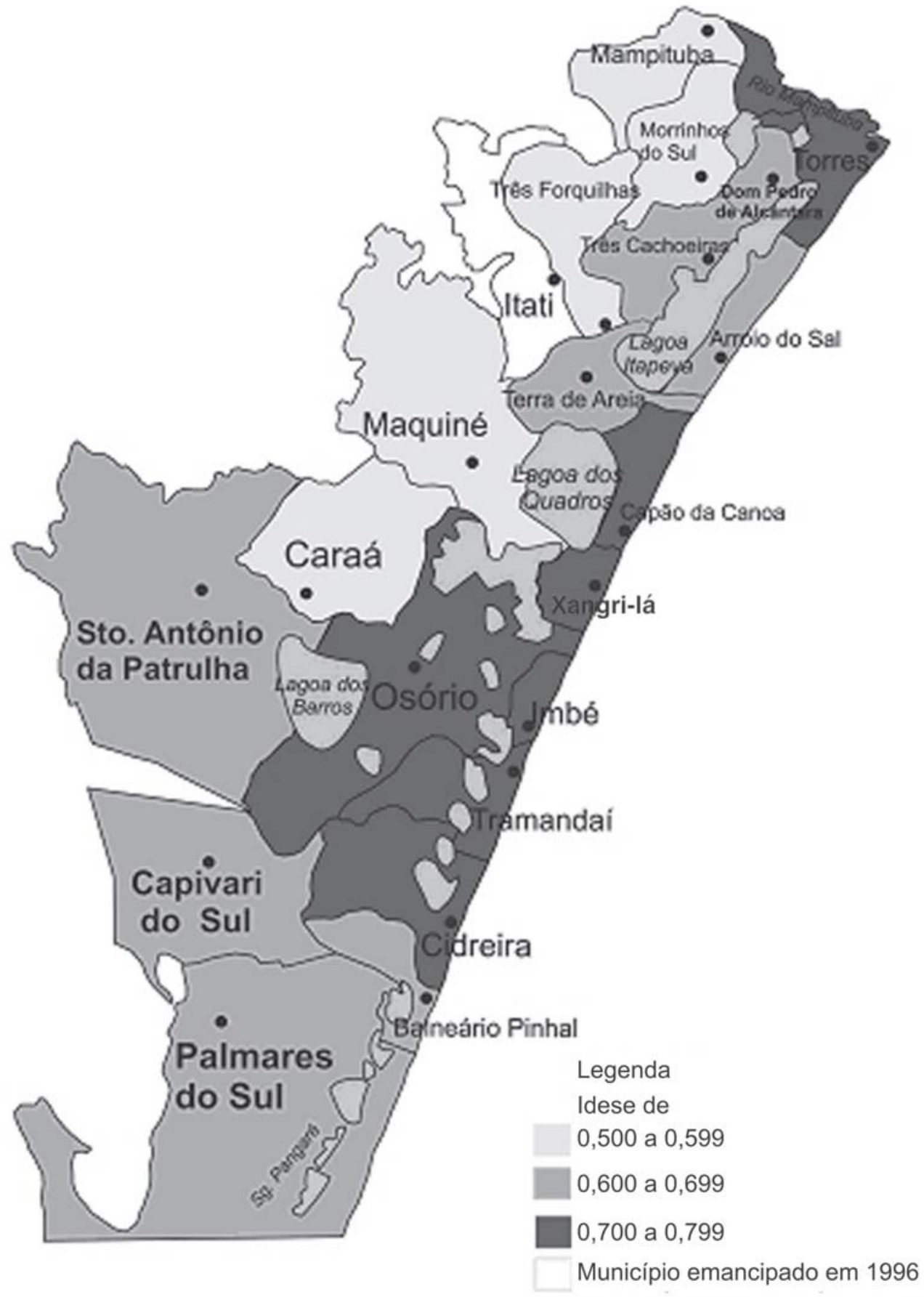


GRÁFICO 1 - VALOR ADICIONADO BRUTO NO LITORAL NORTE DO RIO GRANDE DO SUL

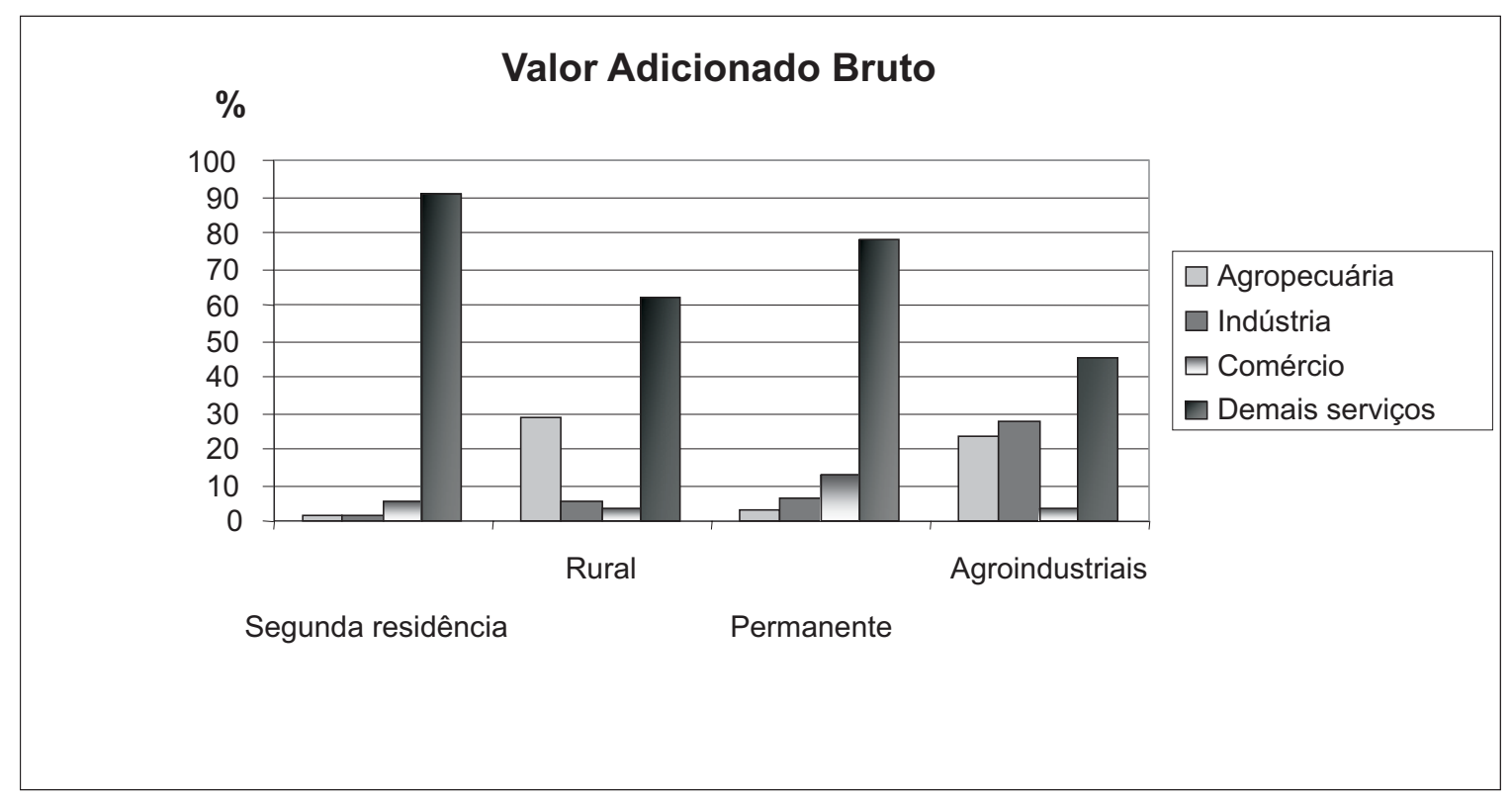

FONTE: Fundação de Economia e Estatística (FEE), 2000.

Elaboração: Subgrupo Temático Uso e Ocupação do Solo IM/Recos/RS.

$\mathrm{Na}$ análise dos dados, representados no Gráfico 1, percebe-se que a grande maioria dos municípios tem sua maior concentração de VAB nos demais serviços, exceto Capivari do Sul e Mampituba, com a predominância da agricultura.

Temos porcentagens significativas do VAB concentradas na agricultura nos seguintes municípios: Capivari do Sul (41,05\%), Caraá (24,83\%), D. Pedro de Alcântara $(19,16 \%)$, Mampituba $(58,51 \%)$, Maquiné $(13,85 \%)$, Morrinhos do Sul (44,69\%), Palmares do Sul $(35,31 \%)$, Terra de Areia (12,99\%), Três Cachoeiras (30,86\%) e Três Forquilhas $(25,70 \%)$. Nesses municípios a população é predominantemente rural, e eles constituem o grupo dos municípios com perfil rural, com exceção de Capivari do Sul e Palmares do Sul, que têm, respectivamente, $77,66 \%$ e $83,78 \%$ de sua população em situação urbana.

Quanto à concentração de VAB na indústria, temos os municípios e as porcentagens do VAB neste setor discriminados a seguir: Balneário Pinhal (7,52\%), Osório $(16,83 \%)$ e Santo Antônio da Patrulha $(35,45 \%)$.

No comércio, temos sete municípios com significativa concentração de VAB, que foram divididos em dois grupos: os municípios urbanos com significativo número de domicílios não ocupados (segunda residência): Arroio do Sal (5,82\%), Cidreira (5,99\%), Imbé (6,75\%) e Xangri-lá $(5,51 \%)$, e os municípios urbanos, cuja maioria dos domicílios são ocupados (domicílios permanentes): Capão da Canoa (10,75\%), Torres $(12,01 \%)$ e Tramandaí $(11,93 \%)$.

\section{Infra-estrutura: abastecimento de água, saneamen-} to e coleta de lixo

Quanto ao abastecimento de água, a maioria dos municípios do Litoral Norte tem seus domicílios abastecidos por poços ou nascentes, como podemos verificar na Tabela 8. Existem sete municípios com porcentagens predominantes em relação ao abastecimento dos domicílios pela rede geral. São eles: Capão da Canoa $(91,55 \%)$, Cidreira (90,15\%), Imbé $(95,31 \%)$, Osório $(79,92 \%)$, Torres $(79,73 \%)$, Tramandaí $(88,80 \%)$ e Xangri-lá $(88,98 \%)$. Contudo, $64 \%$ dos domicílios particulares permanentes do Litoral Norte são abastecidos por rede geral, e 31\% do total de domicílios são abastecidos por poços ou nascentes. A diferenciação deve-se ao maior número de domicíli- 
TABELA 8 - ABASTECIMENTO DE ÁGUA POR DOMICÍLIOS PARTICULARES PERMANENTES

\begin{tabular}{|c|c|c|c|c|c|c|c|}
\hline \multirow{2}{*}{ Municípios } & \multirow{2}{*}{$\begin{array}{c}\text { Total de domicílios } \\
\text { ocupados }\end{array}$} & \multicolumn{6}{|c|}{ Forma de abastecimento de água } \\
\hline & & Rede gera 1 & $\%$ & $\begin{array}{l}\text { Poço ou } \\
\text { nascente }\end{array}$ & $\%$ & Outros & $\%$ \\
\hline Arroio do Sal & 1.624 & 480 & 29,56 & 1.129 & 69,52 & 15 & 0,92 \\
\hline Balneário Pinhal & 2.224 & 989 & 44,47 & 1.211 & 54,45 & 24 & 1,08 \\
\hline Capão da Canoa & 8.812 & 8.067 & 91,55 & 647 & 7,34 & 98 & 1,11 \\
\hline Capivari do sul & 923 & 424 & 45,94 & 495 & 53,63 & 4 & 0,43 \\
\hline Caraá & 1.980 & 16 & 0,81 & 1.435 & 72,47 & 529 & 26,72 \\
\hline Cidreira & 2.771 & 2.498 & 90,15 & 250 & 9,02 & 23 & 0,83 \\
\hline D.Pedro de Alcântara & 835 & 236 & 28,26 & 361 & 43,23 & 238 & 28,50 \\
\hline Imbé & 3.687 & 3.514 & 95,31 & 136 & 3,69 & 37 & 1,00 \\
\hline \multicolumn{8}{|l|}{ Itati * } \\
\hline Mampituba & 910 & 48 & 5,27 & 666 & 73,19 & 196 & 21,54 \\
\hline Maquiné & 2.176 & 21 & 0,97 & 1.345 & 61,81 & 810 & 37,22 \\
\hline Morrinhos do Sul & 1.080 & 332 & 30,74 & 484 & 44,81 & 264 & 24,44 \\
\hline Osório & 10.818 & 8.646 & 79,92 & 2.134 & 19,73 & 38 & 0,35 \\
\hline$\overline{\text { Palmares do Sul }}$ & 3.318 & 1.284 & 38,70 & 1.931 & 58,20 & 103 & 3,10 \\
\hline Sto.Antônio da Patrulha & 11.507 & 5.293 & 46,00 & 5.616 & 48,81 & 598 & 5,20 \\
\hline Terra de Areia & 3.376 & 1.344 & 39,81 & 1.886 & 55,86 & 146 & 4,32 \\
\hline Torres & 9.431 & 7.519 & 79,73 & 1.811 & 19,20 & 101 & 1,07 \\
\hline Tramandaí & 9.144 & 8.120 & 88,80 & 920 & 10,06 & 104 & 1,14 \\
\hline Três Cachoeiras & 2.836 & 795 & 28,03 & 1.817 & 64,07 & 224 & 7,90 \\
\hline Três Forquilhas & 983 & 221 & 22,48 & 517 & 52,59 & 245 & 24,92 \\
\hline Xangri-lá & 2.322 & 2.066 & 88,98 & 251 & 10,81 & 5 & 0,22 \\
\hline Litoral Norte & 80.757 & 51.913 & 64,28 & 25.042 & 31,01 & 3.802 & $\overline{4,71}$ \\
\hline Rio Grande do Sul & 3.042 .039 & 2.423 .264 & 79,66 & 509.413 & 16,75 & 109.362 & 3,60 \\
\hline
\end{tabular}

FONTE: IBGE. Censo Demográfico, 2000.

*Município emancipado em 1996.

Organização: Grupo Uso e Ocupação do Solo-IM/Recos/RS.

os que se situam nos sete municípios em que o abastecimento por rede geral é superior a $70 \%$ dos domicílios abastecidos, inclusive superando a média da região, que é de $64,28 \%$. Os municípios com melhores índices neste quesito têm perfil urbano permanente e urbano de segunda residência.

O saneamento por domicílio particular permanente refere-se à existência, ou não existência, de banheiro ou sanitário, e ao destino do esgoto produzido, rede ou fossa, ou ainda a céu aberto. Neste caso, verifica-se, na Tabela 9, que quase todos os domicílios têm banheiro ou sanitário, e a maior carência ocorre em Mampituba e Maquiné, com respectivamente $10,22 \%$ e $8,59 \%$ de seus domicílios sem banheiro ou sanitário, porcentuais estes acima da média do Litoral Norte, que é de 2,19\%, e do Estado, que é de 2,44\%.
Quanto ao destino do esgoto, a situação é preocupante: $35 \%$ do esgoto da região corre a céu aberto. Isso ocorre em metade dos municípios: Arroio do Sal $(75,85 \%)$, D. Pedro de Alcântara (60,07\%), Mampituba (62,67\%), Maquiné $(63,15 \%)$, Morrinhos do Sul $(93,53 \%)$, Terra de Areia $(94,28 \%)$, Torres $(54,11 \%)$, Três Cachoeiras $(67,68 \%)$, Três Forquilhas $(93,92 \%)$ e Xangri-lá $(51,88 \%)$. Destes municípios, apenas dois são caracterizados como urbanos de segunda residência (Arroio do Sal e Xangri-lá), os demais são municípios rurais, não havendo, portanto, grandes investimentos em saneamento. Já a situação de Torres exige maior atenção, pois este município tem uma significativa população permanente e recebe muitos veranistas todos os anos; há necessidade urgente de investimentos em obras de sanea- 
TABELA 9 - SANEAMENTO POR DOMICÍLIO PARTICULAR PERMANENTE NOS MUNICÍPIOS DO LITORAL NORTE DO RIO GRANDE DO SUL

\begin{tabular}{|c|c|c|c|c|c|c|c|c|c|}
\hline \multirow[b]{3}{*}{ Municípios } & \multirow{3}{*}{$\begin{array}{c}\text { Total de } \\
\text { domicílios } \\
\text { ocupados }\end{array}$} & \multicolumn{8}{|c|}{ Existência de banheiro ou sanitário } \\
\hline & & \multicolumn{6}{|c|}{ Tinham } & \multicolumn{2}{|c|}{ Não tinham } \\
\hline & & $\begin{array}{l}\text { Com banheiro } \\
\text { ou sanitário }\end{array}$ & $\%$ & $\begin{array}{c}\text { Rede ou } \\
\text { fossa }\end{array}$ & $\%$ & Céu aberto & $\%$ & $\begin{array}{l}\text { Sem banheiro } \\
\text { ou sanitário }\end{array}$ & $\%$ \\
\hline Arroio do Sal & 1.624 & 1.611 & 99,20 & 389 & 24,15 & 1.222 & 75,85 & 13 & 0,80 \\
\hline Balneário Pinhal & 2.224 & 2.183 & 98,16 & 1.465 & 67,11 & 718 & 32,89 & 41 & 1,84 \\
\hline Capão da Canoa & 8.812 & 8.709 & 98,83 & 7.789 & 89,44 & 920 & 10,56 & 103 & 1,17 \\
\hline Capivari do sul & 923 & 914 & 99,02 & 739 & 80,85 & 175 & 19,15 & 9 & 0,98 \\
\hline$\overline{\text { Caraá }}$ & 1.980 & 1.905 & 96,21 & 1.574 & 82,62 & 331 & 17,38 & 75 & 3,79 \\
\hline Cidreira & 2.771 & 2.733 & 98,63 & 2.162 & 79,11 & 571 & 20,89 & 38 & 1,37 \\
\hline D.Pedro de Alcântara & 835 & 819 & 98,08 & 327 & 39,93 & 492 & 60,07 & 16 & 1,92 \\
\hline Imbé & 3.687 & 3.664 & 99,38 & 3.264 & 89,08 & 400 & 10,92 & 23 & 0,62 \\
\hline \multicolumn{10}{|l|}{ Itati * } \\
\hline Mampituba & 910 & 817 & 89,78 & 305 & 37,33 & 512 & 62,67 & 93 & 10,22 \\
\hline Maquiné & 2.176 & 1.989 & 91,41 & 733 & 36,85 & 1.256 & 63,15 & 187 & 8,59 \\
\hline Morrinhos do Sul & 1.080 & 1.051 & 97,31 & 68 & 6,47 & 983 & 93,53 & 29 & 2,69 \\
\hline Osório & 10.818 & 10.731 & 99,20 & 8.260 & 76,97 & 2.471 & 23,03 & 87 & 0,80 \\
\hline Palmares do Sul & 3.318 & 3.211 & 96,78 & 2.694 & 83,90 & 517 & 16,10 & 107 & 3,22 \\
\hline $\begin{array}{l}\text { Sto.Antônio da } \\
\text { Patrulha }\end{array}$ & 11.507 & 11.118 & 96,62 & 8.725 & 78,48 & 2.393 & 21,52 & 389 & 3,38 \\
\hline Terra de Areia & 3.376 & 3.197 & 94,70 & 185 & 5,79 & 3.014 & 94,28 & 179 & 5,30 \\
\hline Torres & 9.431 & 9.313 & 98,75 & 4.274 & 45,89 & 5.039 & 54,11 & 118 & 1,25 \\
\hline Tramandaí & 9.144 & 9.022 & 98,67 & 6.010 & 66,61 & 3.012 & 33,39 & 122 & 1,33 \\
\hline Três Cachoeiras & 2.836 & 2.785 & 98,20 & 900 & 32,32 & 1.885 & 67,68 & 51 & 1,80 \\
\hline Três Forquilhas & 983 & 905 & 92,07 & 55 & 6,08 & 850 & 93,92 & 78 & 7,93 \\
\hline Xangri-lá & 2.322 & 2.313 & 99,61 & 1.113 & 48,12 & 1.200 & 51,88 & 9 & 0,39 \\
\hline Litoral Norte & 80.757 & 78.990 & 97,81 & 51.031 & 64,60 & 27.961 & 35,40 & 1.767 & 2,19 \\
\hline Rio Grande do Sul & 3.042 .039 & 2.967 .875 & 97,56 & 2.080 .225 & 70,09 & 887.650 & 29,91 & 74.164 & 2,44 \\
\hline
\end{tabular}

FONTE: IBGE. Censo Demográfico, 2000.

*Município emancipado em 1996.

Organização: Grupo Uso e Ocupação do Solo - IM/Recos/RS.

mento, para impedir o agravamento da balneabilidade de suas praias.

A coleta do lixo é realizada na maioria dos municípios, como demonstra a Tabela 10. No entanto, os municípios de Mampituba, Maquiné e Três Forquilhas apresentam altas porcentagens de domicílios sem coleta de lixo, e são municípios em que a maior parte da população reside em áreas rurais.

Nos municípios onde a maioria do lixo é coletada, poucos ficam abaixo da média do Estado e do Litoral, os quais têm $84,09 \%$ e 86,13\%, respectivamente, do seu lixo coletado, como podemos verificar no Gráfico 4. Os municípios que se encontram um pouco abaixo dessas médias são: Caraá (64,60\%), D. Pedro de Alcântara (77,96\%), Morrinhos do Sul (61,67\%), Santo Antônio da Patrulha $(72,71 \%)$, Terra de Areia $(71,24 \%)$ e Três Cachoeiras (75,04\%). Com exceção de Santo Antônio, os demais municípios são rurais, daí a maior dificuldade em coletar o lixo. 
TABELA 10 - COLETA DO LIXO POR DOMICÍLIO PARTICULAR PERMANENTE

\begin{tabular}{l|r|r|r|r|r}
\hline \multirow{2}{*}{ Municípios } & \multirow{2}{*}{$\begin{array}{c}\text { Total de domićlios } \\
\text { ocupados }\end{array}$} & \multicolumn{4}{|c}{ Destino do lixo } \\
\cline { 3 - 6 } & & Coletado & \multicolumn{1}{c}{$\%$} & Outros & \multicolumn{1}{c}{$\%$} \\
\hline Arroio do Sal & 1.624 & 1.553 & 95,63 & 71 & 4,37 \\
\hline Balneário Pinhal & 2.224 & 2.177 & 97,89 & 47 & 2,11 \\
\hline Capão da Canoa & 8.812 & 8.501 & 96,47 & 311 & 3,53 \\
\hline Capivari do sul & 923 & 790 & 85,59 & 133 & 14,41 \\
\hline Caraá & 1.980 & 1.279 & 64,60 & 701 & 35,40 \\
\hline Cidreira & 2.771 & 2.663 & 96,10 & 108 & 3,90 \\
\hline D.Pedro de Alcântara & 835 & 651 & 77,96 & 184 & 22,04 \\
\hline Imbé & 3.687 & 3.631 & 98,48 & 56 & 1,52 \\
\hline Itati * & & & & & \\
\hline Mampituba & 910 & 296 & 32,53 & 614 & 67,47 \\
\hline Maquiné & 2.176 & 948 & 43,57 & 1.228 & 56,43 \\
\hline Morrinhos do Sul & 1.080 & 666 & 61,67 & 414 & 38,33 \\
\hline Osório & 10.818 & 10.410 & 96,23 & 408 & 3,77 \\
\hline Palmares do Sul & 3.318 & 2.815 & 84,84 & 503 & 15,16 \\
\hline Sto.Antônio da Patrulha & 11.507 & 8.367 & 72,71 & 3.140 & 27,29 \\
\hline Terra de Areia & 3.376 & 2.405 & 71,24 & 971 & 28,76 \\
\hline Torres & 9.431 & 8.969 & 95,10 & 462 & 4,90 \\
\hline Tramandaín & 9.144 & 9.001 & 98,44 & 143 & 1,56 \\
\hline Três Cachoeiras & 2.836 & 2.128 & 75,04 & 708 & 24,96 \\
\hline Três Forquilhas & 983 & 17 & 1,73 & 966 & 98,27 \\
\hline Xangri-lá & 2.322 & 2.289 & 98,58 & 33 & 1,42 \\
\hline Litoral Norte & 80.757 & 69.556 & 86,13 & 11.201 & 13,87 \\
\hline Rio Grande do Sul & 3.042 .039 & 2.558 .120 & 84,09 & 483.919 & 15,91 \\
\hline
\end{tabular}

FONTE: IBGE. Censo Demográfico, 2000.

*Município emancipado em 1996.

Organização: Subgrupo Temático Uso e Ocupação do Solo - IM/Recos/RS.

\section{Principais problemas ambientais nos municípios do Litoral Norte do Rio Grande do Sul}

O levantamento dos principais problemas ambientais do Litoral Norte constou de observação em campo e de entrevistas com técnicos das prefeituras municipais em março de 2004, a partir de uma amostra de municípios representativos das quatro categorias adotadas neste trabalho: municípios urbanos permanentes (Capão da Canoa), urbanos com perfil de segunda residência (Arroio do Sal), urbanos agroindustriais (Capivari do Sul), e municípios rurais (Maquiné), sintetizadas nos Quadros 1 e 2.

A análise das unidades do meio físico com base nas formas de relevo compreende um estudo que engloba as diversas relações entre os componentes da natureza. Esse estudo integrado dos elementos da natureza proporciona uma avaliação da dinâmica da paisagem natural e, desse modo, possibilita construir referências que permitem identificar modificações na dinâmica de uso e apropriação do território pelas atividades humanas. A análise empreendida permitiu diagnosticar os setores mais impactados dos municípios e as prováveis correlações com as atividades econômicas, as práticas e estratégias dos agentes sociais envolvidos.

Entre os principais problemas ambientais identificados nos municípios urbanos agroindustriais (Capivari do Sul) e municípios rurais (Maquiné), podem-se citar:

i) Degradação da cobertura vegetal: a atividade extrativista de espécies nativas de uso ornamen- 


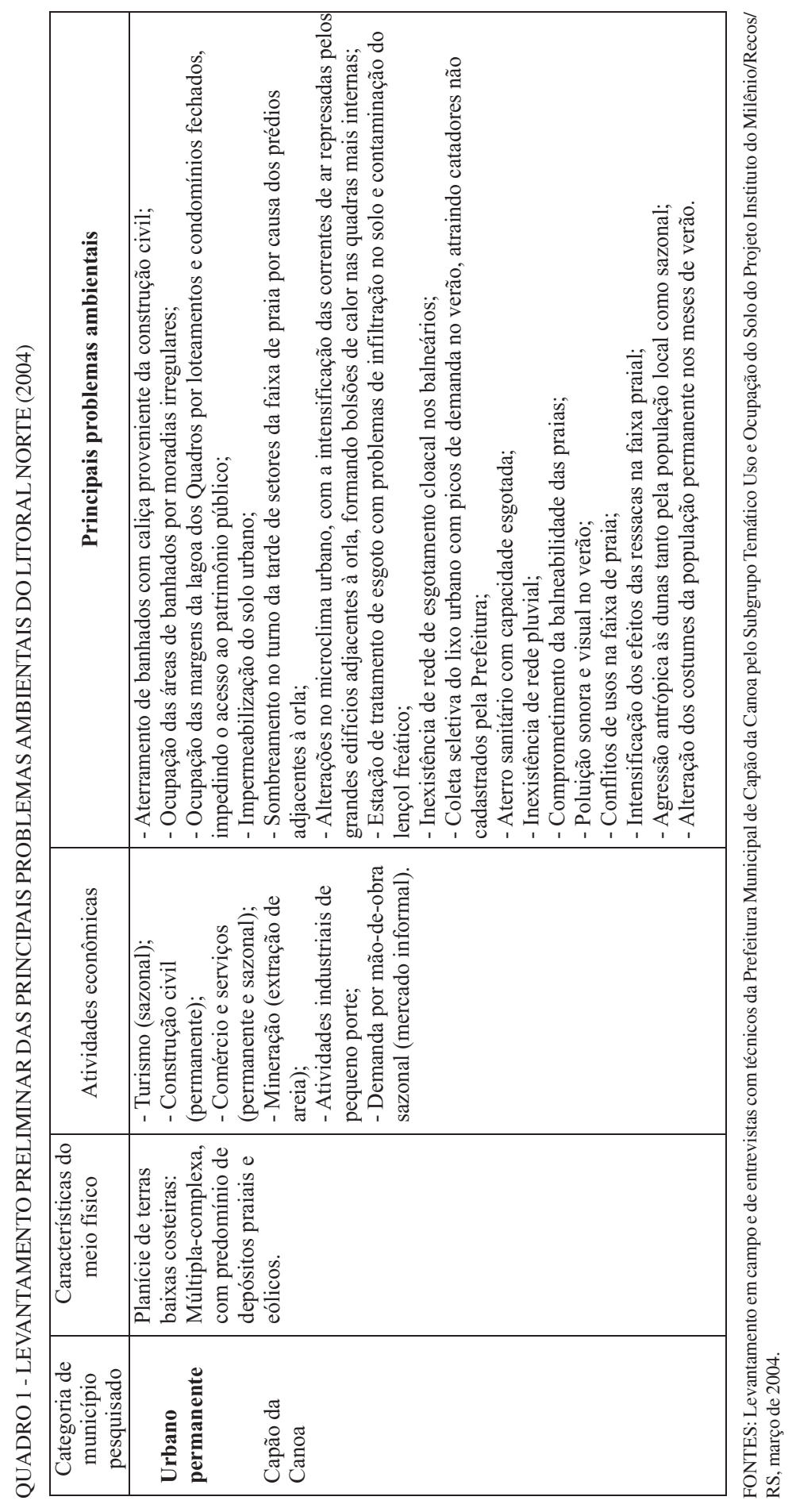




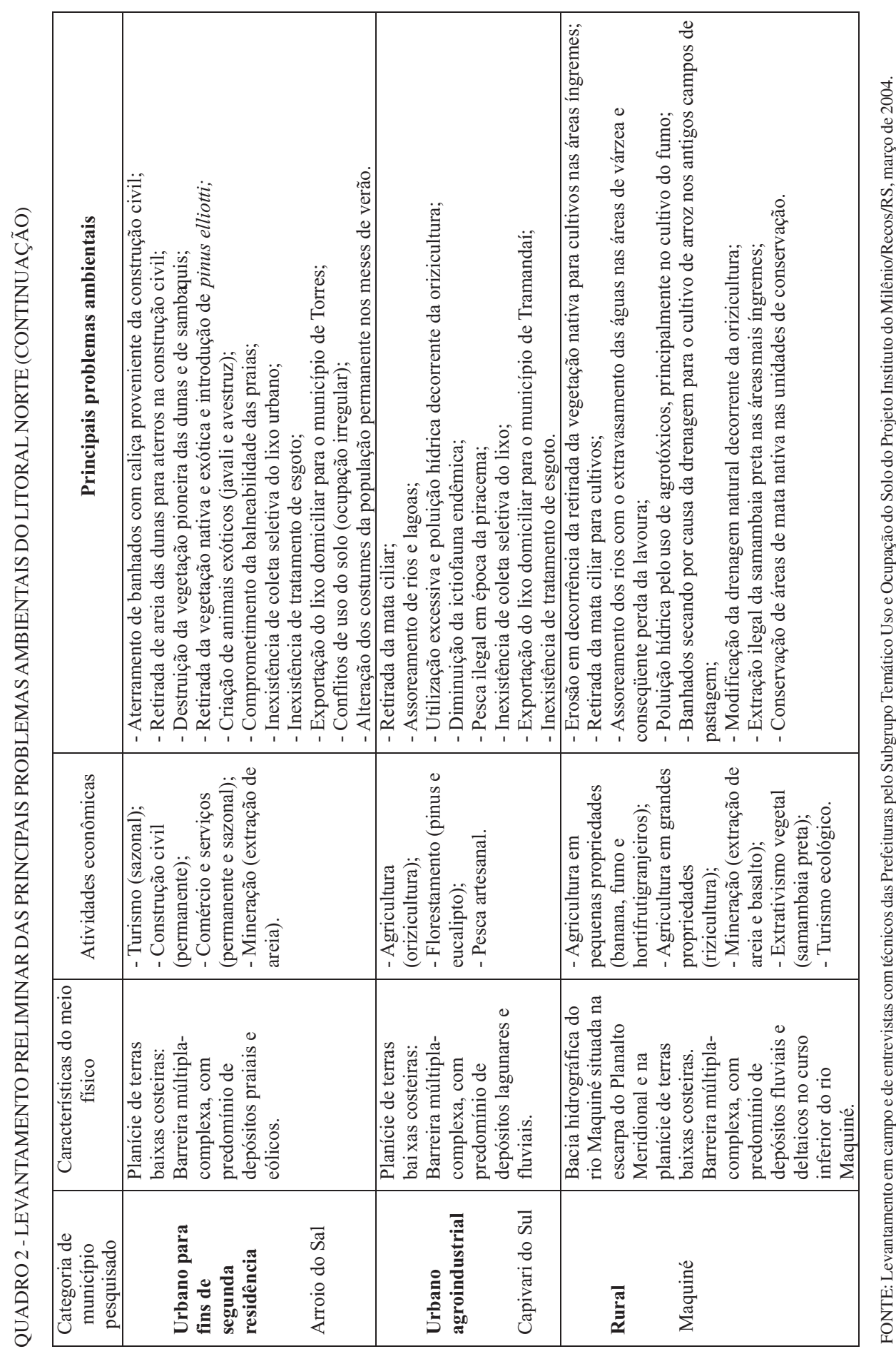


tal (samambaia, orquídeas, bromeliáceas e xaxins) desenvolvida por pequenos agricultores familiares locais e dos arredores promove uma exploração excessiva deste recurso florestal. Convém destacar que a extração de produtos florestais é regulamentada pela legislação federal e estadual e que a fiscalização procura inibir práticas extrativistas de forte impacto. No entanto, segundo Gerhardt et al. (2000), essas práticas são uma decorrência de um longo processo de empobrecimento de uma parte significativa dos pequenos agricultores familiares locais que, para agravar a situação, são confrontados pela ação de alguns atravessadores que dominam o comércio da samambaia-preta, impondo preços baixos aos "samambeiros" (agricultores e moradores que se dedicam à extração de samambaia-preta), obrigando-os a realizar uma intensa exploração das áreas de produção desta espécie de samambaia.

ii) Contaminação das águas superficiais: são constatados em praticamente toda a região problemas ligados ao uso de insumos químicos e agrotóxicos decorrentes da orizicultura, desenvolvida em grandes propriedades nas planícies costeiras, com predomínio de depósitos lagunares e fluviais. $\mathrm{Na}$ bacia hidrográfica do rio Maquiné, de acordo com levantamentos feitos em vários pontos de captação de águas do rio, foram encontrados níveis significativos de contaminação por metais pesados (GERHARDT et al., 2000). Tal contaminação é decorrente do intensivo manejo das áreas de várzeas existentes ao longo do rio Maquiné, principalmente pela produção de hortigranjeiros. Esses sistemas de cultivo requerem uma elevada carga de produtos químicos, adubos minerais ou agrotóxicos. Além desses efeitos de contaminação das águas, a eliminação da vegetação na beira dos rios e o uso inadequado do solo contribuem para o agravamento dos fenômenos de erosão e assoreamento dos rios e lagoas.

Essa situação de poluição ambiental acarreta grave impacto social e ambiental na região, criando um grande impedimento ao desenvolvimento de atividades de grande potencial econômico, como o turismo ecológico, além de comprometer significativamente a atividade pesqueira. De acordo com os relatos dos moradores, ocorreu uma enor- me diminuição na quantidade e na variedade de peixes nos últimos anos no rio Maquiné e nas lagoas costeiras. Muitos associam essa degradação ao uso de herbicidas, fungicidas ou inseticidas no manejo agrícola do arroz irrigado e de outras culturas.

iii) Retirada da cobertura vegetal e alterações na morfologia original: a presença de pedreiras e de empresas de extração de areia promove a retirada da cobertura vegetal nativa e altera a morfologia original dos morros e das planícies. A eliminação da cobertura vegetal nativa ocorre em uma área reconhecida pela Unesco, desde 1992, como Reserva da Biosfera da Mata Atlântica. Em seguida, ocorrem modificações na morfologia a partir da elaboração de cortes e da criação de superfícies expostas ligadas à mineração. A modificação do relevo promove a criação, indução e intensificação ou modificação do comportamento nos processos geomorfológicos, gerando novos padrões de comportamento morfodinâmico (FUנIMOTO, 2001). Em geral, rompe-se a dinâmica geomorfológica natural e passa-se a intensificar os processos erosivos e deposicionais.

As atividades agrícolas, particularmente aquelas desenvolvidas em pequenas propriedades junto à escarpa do Planalto Meridional, em terrenos com declividades acentuadas e sem uso de técnicas adequadas, tem promovido o desmatamento de importantes resquícios da Mata Atlântica e contribuído para o surgimento de processos erosivos e de degradação do solo.

As categorias dos municípios urbanos permanentes e daqueles para fins de segunda residência apresentam problemas ambientais concentrados no perímetro urbano de caráter similar, mas com intensidades distintas.

A carência de infra-estrutura, por exemplo, é comum às duas categorias de municípios, no entanto, por causa do volume de dejetos (líquidos e sólidos) considerável nos municípios urbanos permanentes, há uma preocupação maior do poder público em transformar a geração de resíduos em fonte de renda para as camadas sociais marginalizadas, aí presentes em maior número. Por outro lado, os municípios urbanos para fins de segunda residência geralmente não investem no setor de saneamento, procurando transferir os problemas com a "exportação" dos resíduos sólidos para municípios vizinhos de maior porte, e adotando as fossas sépticas como modelo de esgotamento cloacal. 
Os impactos ambientais decorrentes do processo de urbanização apresentam:

i) concentração longitudinal à orla marítima e lacustre principalmente no período de verão;

ii) expansão nos vetores de ocupação irregular em setores vulneráveis e de difícil acesso, como fundos de loteamentos antigos e áreas de banhados;

iii) ampliação nos setores urbanos impermeabilizados.

Sintetizando, os setores urbanos mais valorizados economicamente apresentam uma densificação maior e, consequientemente, estão sujeitos a maiores pressões antrópicas ainda que sazonalmente. Nos setores urbanos de ocupação permanente observa-se carência de infra-estrutura e crescente informalidade na obtenção da moradia.

O conjunto de problemas ambientais apresentados no Litoral Norte mostra as formas predatórias de apropriação da natureza pela sociedade. A análise, ainda que preliminar, de quem produz e como se produzem os espaços degradados reflete as condições sociais e econômicas no âmbito local, onde a degradação ambiental tem sido fruto de uma relação dos grupos sociais com a natureza.

\section{Considerações finais}

A região do Litoral Norte, um dos segmentos da Zona Costeira do Rio Grande do Sul, distingue-se pela sequiência de ambientes longitudinais à costa. Após a área de interface com o mar, identifica-se uma planície sedimentar costeira, constituída por dunas, além de um rosário de lagoas litorâneas, chegando até as escarpas do Planalto Meridional, entalhadas pelos vales dos rios Maquiné e Três Forquilhas.
As relações sociedade-natureza ampliaram-se nas últimas décadas e, em especial, na Zona Costeira por causa, entre outros fatores, do processo de urbanização. A ocupação e a apropriação da Zona Costeira do estado do Rio Grande do Sul tomou vulto a partir do século XX, quando a demanda pelos agentes econômicos tornou-se mais efetiva. Os investimentos públicos e privados empreendidos a partir dos anos 1930 impulsionaram o crescimento demográfico e a diversificação econômica. No entanto, esse rápido crescimento ocasionou uma série de problemas para um ambiente caracterizado por ecossistemas diversificados e de grande suscetibilidade.

A análise do índice de desenvolvimento socioeconômico classifica a região dentro de um perfil de médio desenvolvimento. Os investimentos em saúde e educação realizados nos últimos anos melhoraram sensivelmente os indicadores da região. No entanto, é necessário canalizar mais recursos em setores-chave, principalmente no tocante à demanda pelo ensino médio, ao abastecimento de água por rede geral, à rede coletora e destinação do esgoto cloacal e ao destino final dos resíduos sólidos.

As alterações ambientais mais significativas, exacerbadas nos meses de dezembro a março, são o abastecimento e a qualidade das águas, a ampliação na demanda por serviços de saúde, a balneabilidade das praias, o esgotamento sanitário, a disposição dos resíduos sólidos, os conflitos de uso na faixa de praia, a ampliação no número de moradias irregulares, poluição hídrica, sonora e poluição visual, desrespeito ao meio ambiente, entre outros.

As potencialidades da região estão associadas às características físicas, ambientais, econômicas e culturais. Neste sentido, existe uma diversidade de potencialidades no Litoral Norte que pode vir a se constituir em importante elemento para o desenvolvimento e gerenciamento integrado. 


\section{Referências}

ALMEIDA, F. F. M. Diferenciação tectônica da plataforma brasileira. In: CONGRESSO BRASILEIRO DE GEOLOGIA, 23., 1969, Salvador. Anais... Salvador, 1969. p. 29-46.

FUJIMOTO, N. S. V. M. Análise ambiental urbana na área metropolitana de Porto Alegre-RS: sub-bacia hidrográfica do Arroio Dilúvio. São Paulo, 2001. Tese (Doutorado) - Faculdade de Filosofia, Letras e Ciências Humanas, Universidade de São Paulo.

FUJIMOTO, N. S. V. M. Análise geomorfológica de Itapuã norte da Laguna dos Patos. Revista do Departamento de Geografia, São Paulo, n. 11, p. 67-93, 1997.

FUJIMOTO, N. S. V. M; STROHAECKER, T. M; KUNST, A. V.; FERREIRA, A. H. Uso e ocupação do solo no litoral norte do Estado do Rio Grande do Sul. In: ENCONTRO DE GEÓGRAFOS DAAMÉRICA LATINA, 10., 2005, São Paulo. Anais... São Paulo, 2005. p. 5575-5591.

GERHARDT, C. H. et al. Caracterização do meio rural do município de Maquiné - RS: subsídios para um desenvolvimento rural sustentável. Porto Alegre, 2000. Relatório de pesquisa - Associação Ação Nascente Maquiné (Anama), Programa de Pós-Graduação em Desenvolvimento Rural (PGDR/ UFRGS) e Prefeitura de Maquiné.
GONÇALVES, J. M. S.; SANTOS, N. M. Análise das classificações do relevo para o Rio Grande do Sul. Boletim Gaúcho de Geografia, Porto Alegre, n. 13, p. 3-20, 1985.

HORN FILHO, N. O. Geologia das Folhas Torres, Três Cachoeiras, Arroio Teixeira e Maquiné, Nordeste do Rio Grande do Sul. Porto Alegre, 1987. Dissertação (Mestrado) - Instituto de Geociências/UFRGS.

RIO GRANDE DO SUL. Atlas sócio-econômico do Estado do Rio Grande do Sul. Porto Alegre: Secretaria da Coordenação e Planejamento do estado do Rio Grande do Sul, 2002.

RIO GRANDE DO SUL. Diretrizes ambientais para o desenvolvimento dos municípios do litoral norte. Porto Alegre: Fepam/ Programa de Gerenciamento Costeiro, 2000. (Cadernos de Planejamento e Gestão Ambiental, v. 1).

SUERTEGARAY, D. M. A.; FUJIMOTO, N. S. V. M. Morfogênese do relevo do Rio Grande do Sul. In: VERDUM, R.; BASSO, L. A.; SUERTEGARAY, D. M. A. Rio Grande do Sul: paisagens e territórios em transformação. Porto Alegre: Editora da Universidade/UFRGS, 2004. p. 11-26.

VILLWOCK, J. A.; TOMAZELLI, L. J. Geologia costeira do Rio Grande do Sul. Notas Técnicas, Porto Alegre, Centro de Estudos de Geologia Costeiras e Oceânicas/ UFRGS, n. 8, p. $1-45,1995$. 